\title{
ヒト口腔に見られた囊胞上皮の走査並びに 透過電子顕微鏡による形態学的研究
}

\author{
福岡歯科大学口腔外科学第一講座（指導：富岡徳也教授）
}

橋本滋

昭和 61 年 2 月 22 日受付

\section{Scanning and Transmission Electron Microscopic}

Study of Epithelium at Cyst Developing in Human Oral Region

Shigeru Hashimoto

First Department of Oral Surgery (Director: Prof. Tokuya Tomioka)

Fukuoka Dental College, Fukuoka Japan

Twenty-three cases of odontogenic cysts (10 radicular cysts, 10 follicular cysts and 3 calcifying odontogenic cysts) and 10 cases of non-odontogenic cysts (3 median mandibular cysts, 2 median maxillary cysts, 3 nasoalveolar cysts and 2 nasopalatal cysts) developing in the human maxillo-oral area were examined by scanning and transmission electron microscopes.

I . Odontogenic cysts

A. Radicular cysts

The decrease of nuclei and organellae in superficial cytoplasms was remarkable and a number of vascular structures were observed. The superficial cell surface with unclear borderline was covered with microridge.

B. Follicular cysts

1. Dentigerous cysts

The superficial cytoplasm was cuboid and there were many mitochondrias and vascular structures in the cell without the nucleus.

The superficial cell surface was arranged irregularly with hemisphere form cell, and the boundary was clear.

2. Primodial cysts

The horney layer of epithelium showed flat and stratified form and the inside of cells was filled with tonofilament bundles. Superficial cytoplasm showed turtleback pattern and the surface was covered with network structure microridge.

C. Calcifying odontogenic cysts

The figure of ghost-cell observed by scanning electron microscope showed network structure with irregularly arranged filaments and by transmission electron microscope showed tonofilament bundles but no organellaes. The superficial surface was flat and covered with short microridge. 
II . Non-odontogenic cysts

A. Median maxillary cysts

The superficial cytoplasm showed high density and was flat, and the cells were connected like twigs. The superficial cell surface was rough and scale-like in appearance and was covered with granulated microridge.

B. Median mandibular cysts

The hemisphere cells were arranged like paving stones in the surface epithelial layer and the boundary form was leveelike. The cell surface was covered with microridge that showed network, pit and concave structures.

C. Nasoalveolar cysts

The superficial cytoplasm showed cylindrical form with its nucleus placed near the basal side and the organellae growth was good. The cell surface looked like cauliflower.

D. Nasopalatal cysts

The superficial cytoplasm showed cuboid or cylindrical form. Its nucleus was placed near the basement membrane, and the organellae growth was good. The surface appeared like paving stones or an arrangement of sticks. The surface of cells as covered with granular like or fold like microridges.

Key words : Odontogenic cysts/Non-odontogenic cysts/Epithelium/SEM/TEM

緒言

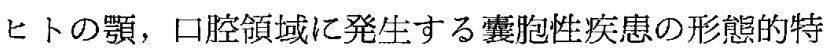
徵については各方面より多くの研究がなされている.ま ず囊胞壁の表面および断面の形態についての透過電顕的 研究は Frithiof ら $(1966)^{11}$, Hansen ら $(1970)^{2}$, , Fejerskov ら $(1972)^{31}$, Chen ら $(1975)^{4)}$, 新藤ら $\left(1972^{51}, 1979^{6)}\right)$, 岩佐ら $\left(1974^{7)}, 1975^{81}\right)$, 高田ら $\left.(1980)^{9}\right)$ ，佐藤ら $\left.(1985)^{10}\right)^{1}$ 亿よる業續が見られ，走查 電顕を使用したものとしては永田 $(1981)^{11}{ }^{11}$ の報告がみ られる・しかし，透過並びに走查電顕の併用観察を試み たものは若江 $(1982)^{121}$, 広沢ら $(1982)^{13}{ }^{1}$ の研究を見 るに過ぎず，現在まで囊胞内壁の表面棈造についても未 だ充分な追求がなされていない様である，そこで著者は

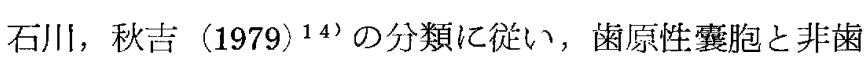
原性震胞と㟝断された試料の各囊胞上皮表面構造と構築 を走查型並びに透過型電顕にて観察するとともに従来の 所見と比較検討を試みた。 それによって若干の知見を得 たので報告する．

\section{試料ならびに観察方法}

研究試料は昭和 49 年 1 月から昭和 58 年 12 月までの期
間, 福岡歯科大学附属病院第一口腔外科で処置され, 臨 床ならびに病理組織学的に歯原性霊胞（雬根靁胞, 滤胞 性歯霊胞, 石灰化歯原性囊胞) および非歯原性襄胞（上 頱正中囊胞, いわゆる下顎正中囊胞, 鼻口蓋管霊胞, 鼻

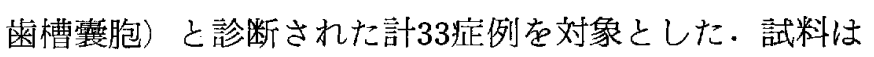
すべて局所麻酔あるいは全身麻酔下で，七トの䭭，口腔 領域より摘出されたものを用い，光顕用と電顕用とに 2 分割した。

光顕用試料は $10 \%$ 中性ホルマリンにて固定後, 水汽, 上昇アルコール系列にて脱水, パラフィン包埋, 連続切 片を作製後， H-E 染色を施し，必要に応じてアザン， PAS 染色などを試みて検討の試料とした。

電顕用試料は採取後直ちに生理食塩水にて洗浄後, 走査電䫓用には $2.5 \%$ グルタールアルデヒド溶液（pH $\left.7.4,2 \sim 4{ }^{\circ} \mathrm{C}\right)$ にて 2 時間前固定， $1 \%$ 緩衝才スミウ ム酸溶液 $\left(\mathrm{pH} 7.4,2 \sim 4{ }^{\circ} \mathrm{C}\right)$ にて 2 時間後固定を行 なった・上昇アルコール系列脱水，イソアミルアセテー トにて置換, 浸漬して臨界点乾燥（HCP-1 装置）を経 て金の蒸着を施し, 日本電子 JSM-T-20 型並びに日立 HFS- 2 型走査電顕を 用いて観察した。透過電顕用には 試料を緩衝液にて洗浄, 細切, $2.5 \%$ 緩衝グルタールア ルデヒド溶液 $\left(\mathrm{pH} 7.4,2 \sim 4{ }^{\circ} \mathrm{C}\right)$ にて 2 時間前固定， 
$1 \%$ 緩衝才スミウム酸 $\left(\mathrm{pH} \mathrm{7.4，2 \sim 4}{ }^{\circ} \mathrm{C}\right)$ で 2 時間 後固定後アセトン系列にて脱水, プロピレンオキ+イト にて置換，Epon 812 樹脂に包埋，重合後，MT- 1 型 ウルトラミクロトームで超薄切片を作製し, ウラニルア セテートとリードアセテートの二重染色を施して，日本 電子 JEM-100 B 型並びに日立 HU-12 AS 型透過電顕 にて観察した・なお，オリエンテーションの目的で Epon 812試料より約 $1 \sim 2 \mathrm{~mm}$ の切片を作製し, トルイ ジン青染色を施し, 走査並びに透過型電顕観察の参考に 共した。

\section{観 察 所 見}

I . 粜原性囊胞

\section{A. 歯根囊胞}

\section{1. 光顕所見}

観察した10症例における霣胞の多くは数層の重層上皮 細胞で裏装されている・上皮下結合組織には炎症性細胞 の浸潤が著明に認められ，一部には毛細血管の拡張が顕 著である。

\section{2 . 走查電顕所見}

囊胞上皮細胞遊離表面は全体的にゆるやかな波状を呈 するが，各々の細胞は平坦な多角形を呈し，石畳状の配 列を示す，細胞境界はすべて明瞭であるとは限らない。 上皮細胞間には部分的に大小不同の円形あるいは半月状
の小孔が頻繁に認められ，その小孔を通ってリンパ球， 白血球と䍐われる球状，星形の構造物が突出している (Fig. 1).

強桩大像では，その遊離表面には不規則に配列する微 小堤とその間に短いイガグリ状の微絾毛が観察される (Fig. 2).

\section{3 . 透過電顕所見}

霊胞上皮細胞層は基底層，有棘層，表在層に大別され る. 有棘層上部の細胞の核は比較的大きく細胞質の大部 分を占めている。ミトコンドリア，遊離リボゾーム等の 発達は不良で，トノフィラメント束の形成も顕著ではな い. この部の細胞間隙が著しく拡大されている．表在細 胞は細胞内小器官に乏しく，代りに空胞椂構造物が顕著 に認められる。隣接する細胞間は各所でデスモゾームで 接合され，それら細胞の遊離面には長さ約 $0.1 \sim 0.3 \mu \mathrm{m}$ の微絨毛の断面が認められる (Fig. 3).

B . 濾胞性䨑囊胞

観察に供した10症例のうち，蒾冠を含んだ含雪性囊胞 は 5 症例，歯牙硬組織を含まない原始性䨳胞（無歯性滤 胞性歯囊胞) は 5 症例であった。

\section{1 . 光顕所見}

含霆性囊胞 5 症例のうち，そのほとんどは肥厚した線 維性結合組織とその内側は数層の非角化性扁平上皮加ら 成る. 一方, 原始性襄胞全症例の鼠胞内壁は10数層の重

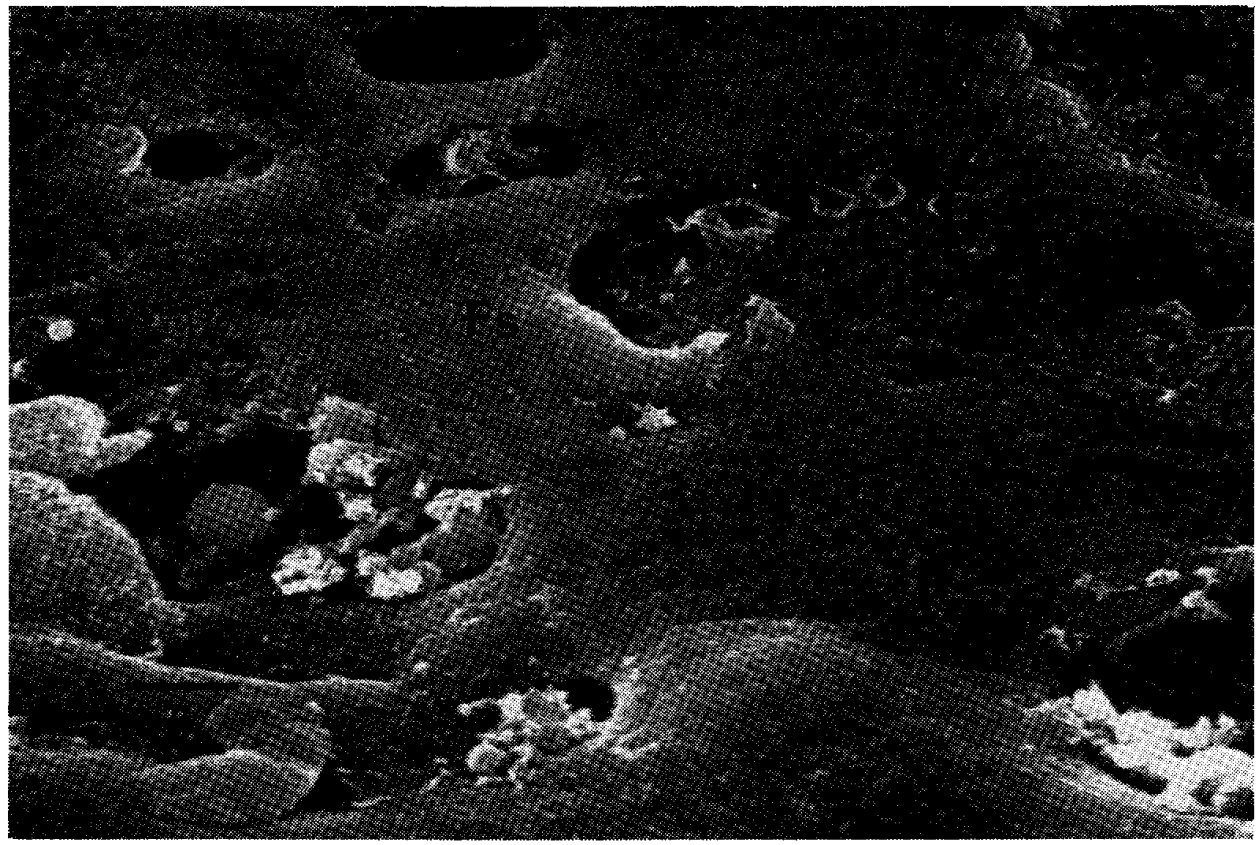

Fig. 1 霜根囊胞上皮細胞遊離表面の走查電顕像

上皮細胞首の遊離表面（Fs）は平坦で，細胞間には大小の間隔が認めら れ，その間隙には間葉系由来の細胞が存在する。 $\quad(\times 3,000)$ 


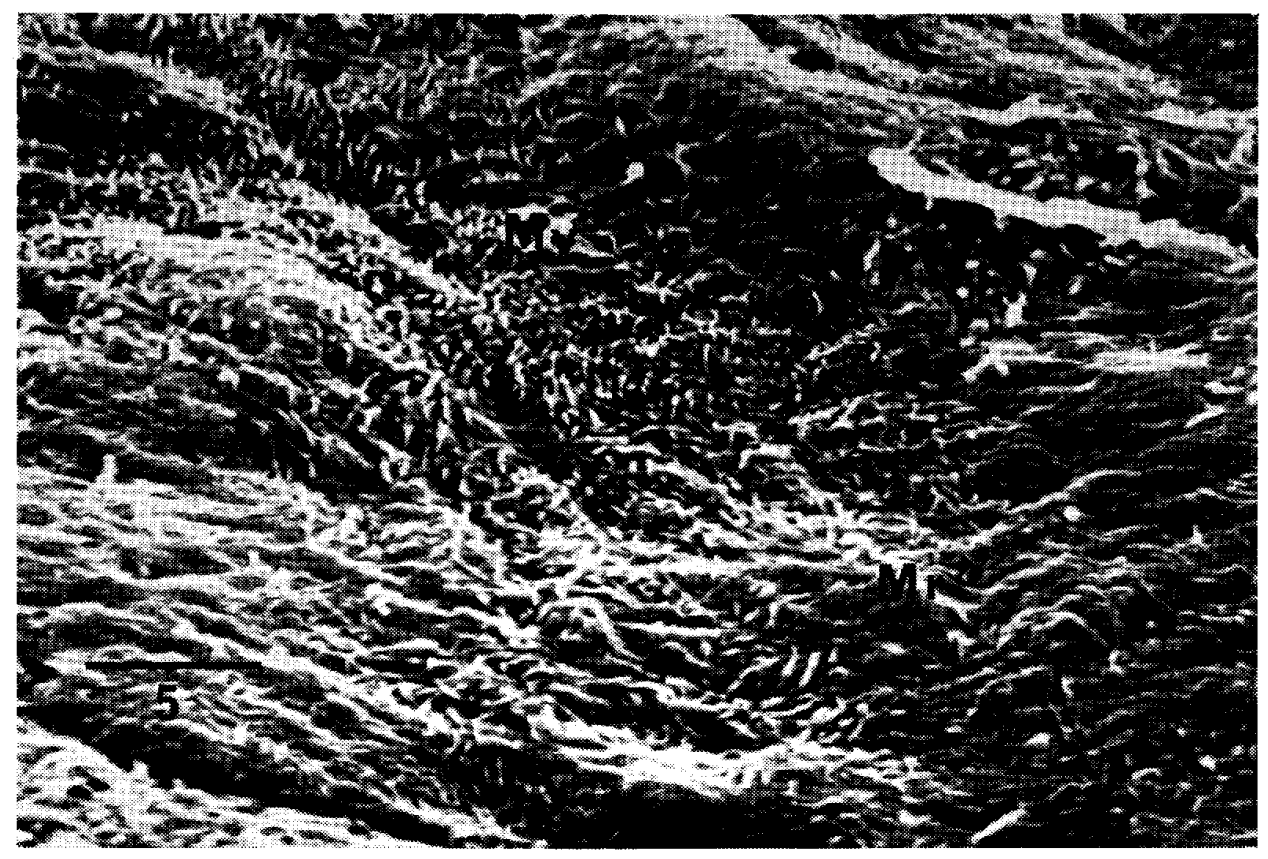

Fig. 2 歯根囊胞上皮細胞の走査電顕像の強拡大 上皮細胞層の遊離表面は微小堤 $(\mathrm{Mr})$ と一部には微縅毛 $(\mathrm{Mv})$ で覆われ ている. $(\times 5,000)$

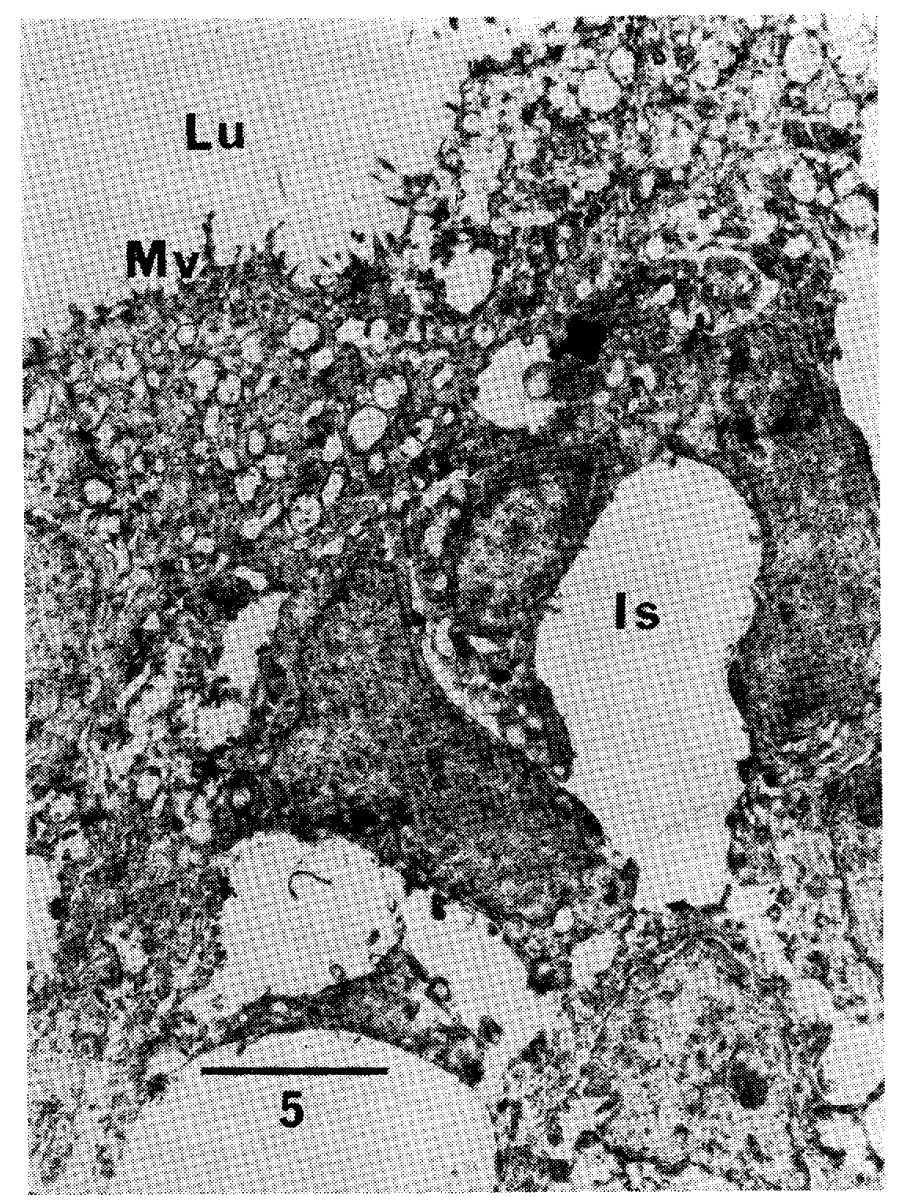

Fig. 3 橉根震胞上皮の透過電顕像

上皮細胞層の最表在細胞は空胞様構造が著明であ

り，遊離面には微紱毛 $(\mathbf{M v})$ が認められる.

Lu：囊胞腔 Is：細胞間空陌 $\quad(X, 5000)$ 
層扁平上皮で被覆され，その上皮層は基底細胞首，有棘 層および角質層から構成されている。

\section{2 . 走查電顕所見}

a . 含蒌性囊胞

囊胞上皮細胞遊離表面は山凸不整で，大小不同の隆起 様あるいは半球状に膨隆した細胞が不規則に配列し，そ れら細胞間は裂溝状を示す。したがって，境界は比較的 明瞭である (Fig，4). 半球状または隆起状を示す細胞 の遊離表面には無数の屈曲した網目模様の微小堤が観察 される.これら細胞群の中には㤥の存在を暗示させる大 きな隆起を持った細胞も認められる．細胞間の山部には 時として, 直径約 $4 \sim 6 \mu \mathrm{m}$ の円形の小孔が認められ, その小孔より白血球，またはりンパ球と思われるサボテ ン様または球状構造物の存在が認められる（Fig．5）。

\section{b . 原始性震胞}

上皮層の割断面をみると，有棘層から角質首にいたる 上皮細胞は扁平化が著しく，その配列は比較的規則正し く重層している。遊離表面は扁平に引伸ばされた多角形 細胞が波状の走行を措きながら配列している(Fig．6).

最表層の上皮細胞はゆるやかな起伏を示しているが， 一部には上皮細胞が剝離傾向を示す像も観られる。それ ら細胞の遊離表面は比較的平坦で粗造な網目様構造や顆 粒状を呈する微小堤に被われている（Fig．7）.

3 . 透過電顕所見

a . 含蒾性襄胞

最表層の上皮細胞は立方状または低円柱状を示し, 細 胞内には $1 \sim 3 \mu \mathrm{m}$ の球形のミトコンドリアや空胞様樍 造物が多数散在する。後者には，時に微細顆粒状物質を 容れたものも存在する・トノフィラメント東の形成は著 明ではない，遊離側の細胞膜上に高電子密度の小顆粓が 規則正しく配列しているが，その物質は不明である.隣 接する細胞間隙は狭く，デスモゾームで接着されてい る 、時には細胞間腺は著しく拡大傾向を示すこともあ り，そこには細胞側面から突出した小突起が珰められ る. 走査電顕で観察された遊離表面の小孔は透過電顕で 観察した細胞間の陷凹と同一のものと考えられる（Fig． 8 ).

\section{b . 原始性囊胞}

有棘層から角質層にかけての上皮細胞は扁平化を示 し，上下に層板様に配列する．それらの細胞には Golgi 装置, 粗面小胞体はほとんど消失し, 空胞様に変性した そトコンドリア, 不規則配列を示すトノフィラメント東 間にやや高い電子密度を有するケラトヒアリン顆粒（直 径約 $0.2 \sim 1 \mu \mathrm{m}$ ) や類円形を呈する限界膜を持った層板
顆粒（直径約 $0.3 \sim 0.5 \mu \mathrm{m}$ ) などが認められる.さらに 表層に進むと細胞の扁平化が著しく, 最表層細胞では厚 さ約 $0.2 \sim 0.5 \mu \mathrm{m}$ と菲薄化する. 細胞内はトノフィラメ ントで満たされ，細胞膜は肥厚した感じを与え，遊離面 には短い絨毛梯突起が認められる（Fig．9）。

C. 石灰化歯原性囊胞

1 . 光顕所見

観察に供したのは 3 症例である . 囊胞壁は比較的肥厚 した線維性結合組織とその内側にある Ghost cell p石 灰化巣を含む肥厚した緻密な上皮細胞層よりなるＧ－ host cell を取り巻く上皮基底部の細胞は円柱状を呈 し，その内側にエナメル髄に似た構造を呈する星状細胞 がみられる。また，石死化傾向が著明な部分では重皇扁 平上皮が直接石灰化している部分と上皮組織により生じ た角化物, 石灭化物が囊胞内に堆積している部分がみら れる。

\section{2 . 走查電顕所見}

囊胞上皮は凹凸起伏が著しく，その配列は不規則で， 真珠様, 玉ネギ状など多種多様な形態を示す大小不同の Ghost cell を含む重層扁平上皮首より成っている. 類

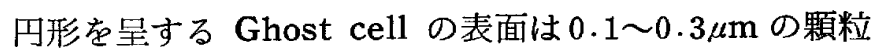
状の微小堤をそなえている. Ghost cell の割断面像で はその胞体内に多数の線維椂構造物が不規則に走行し， 互いにからみ合い網状配列を示している．その網目の間 隔は不規則で大小不同を示し，辺縁部に進むに從いより 密になる (Fig. 10)。

\section{3 . 透過電顕所見}

上皮紐胞層は肥厚が著しく，それらの細胞層は基底細 胞層, 有棘層, 角質層に大別される.本疾患の特徽であ る Ghost cell は有棘層内に多く観察される. Ghost cell は類円形を呈し, その胞体は不規則配列の太いトノ フィラメント束で満たされており，核やミトコンドリア などの細胞内小器官はほとんど認められない，Ghost cell を取り巻く上皮は一般に扁平な角化細胞により層板 配列を呈し，これらの角化細胞も Ghost cell と同じよ うに細胞内小器官をほとんど持たずトノフィラメントの みで満たされており，部分的には石灭化を暗示する高電 子密度の領域も観察される.上皮細胞層の遊離面は比較 的平坦で微小突起が散見される（Fig，11）.

II . 非歯原性䨳胞

\section{A . 上領正中震胞}

\section{1 . 光顕所見}

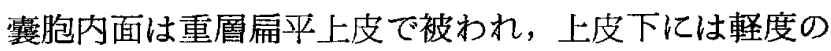
炎症性細胞の浸潤, 浮腫を伴なう線維性結合組織を認め 


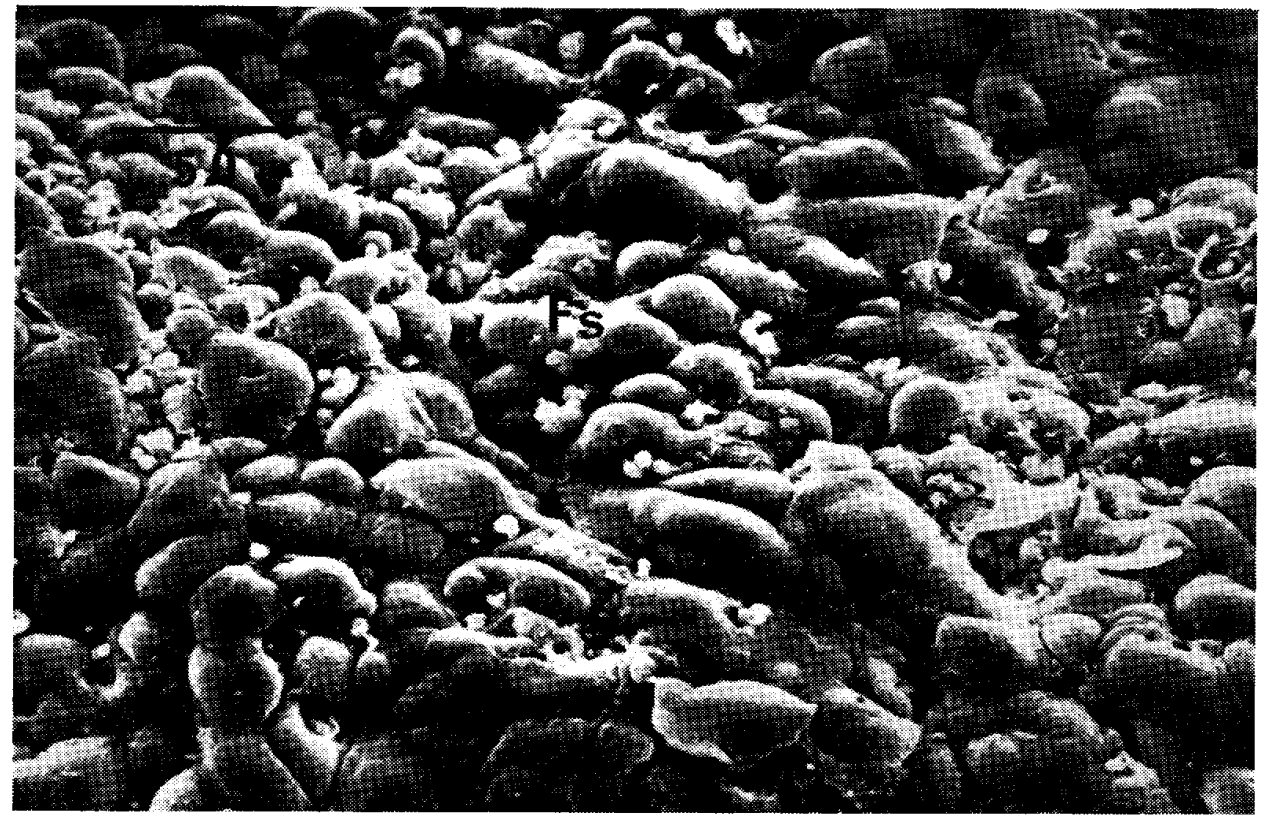

Fig. 4 滤胞性雬襄胞（含䨑性霊胞）の走查電顕像

上皮細胞層の遊離面 (Fs) は四山不整で，大小不司の半球形の細胞が不規

則に配列している。 $(\times 500)$

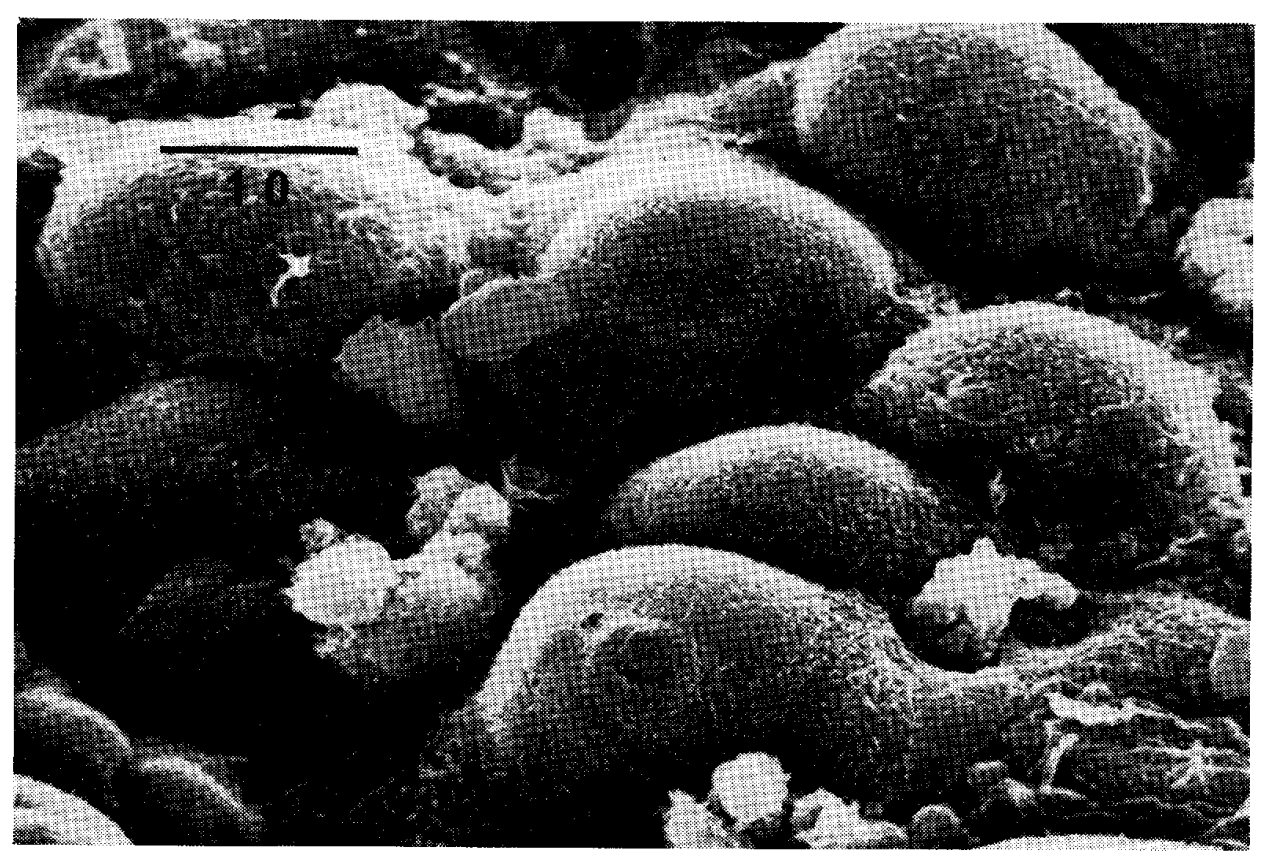

Fig. 5 滤胞性東囊胞 (含䨑性囊胞) の走査像の強拡大

半球形状の上皮細胞遊離面には豊富な網目模様の微小堤様物が認められ

る。細胞閻の小孔から自血球やリンパ球が突出している.

$(\times 2,500)$ 


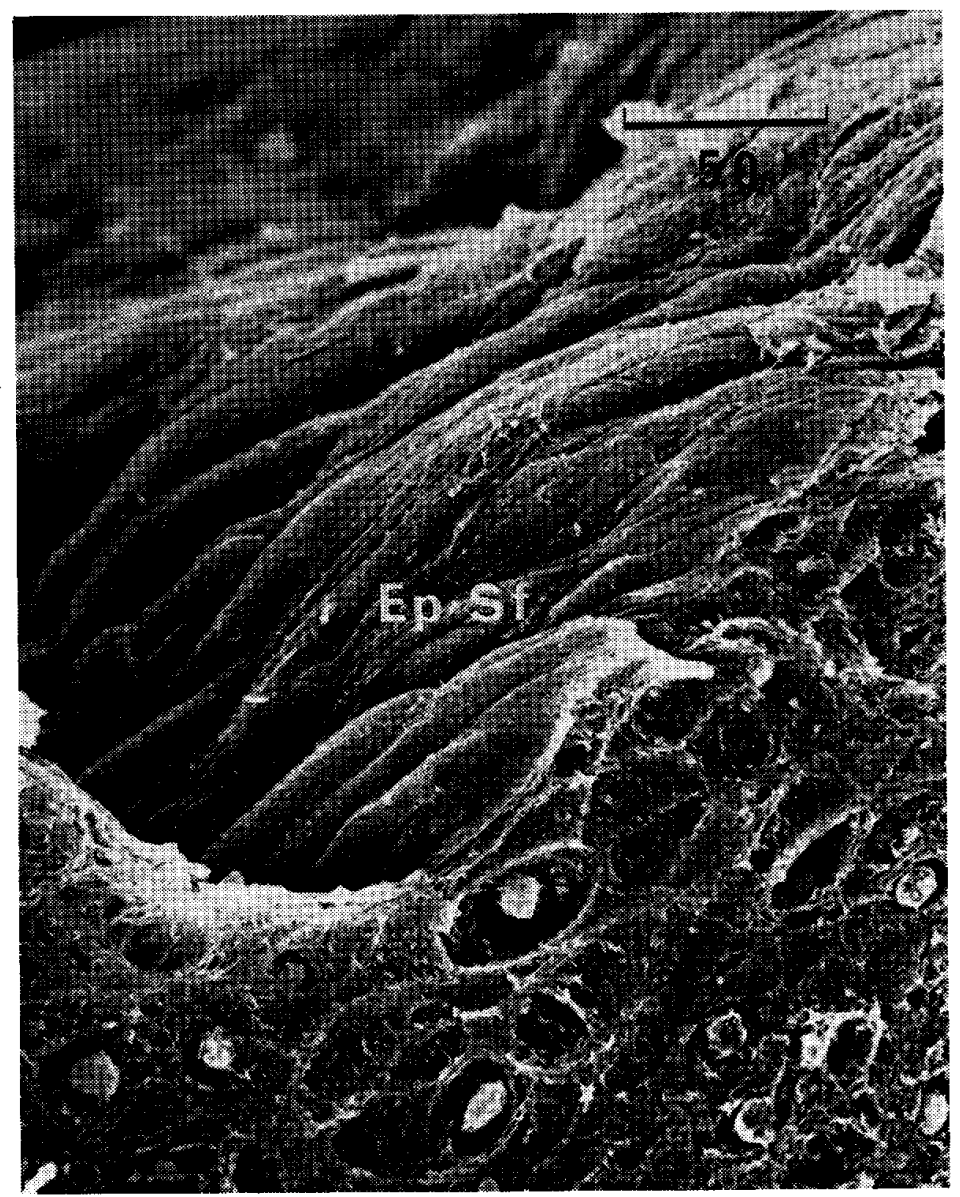

Fig. 6 濾胞性蒾囊胞 (原始性雯胞) の走查電顕像 上皮細胞の表面は波状の走行を呈し, 下方の断面像では上 皮の累積と球形の核が目につく。

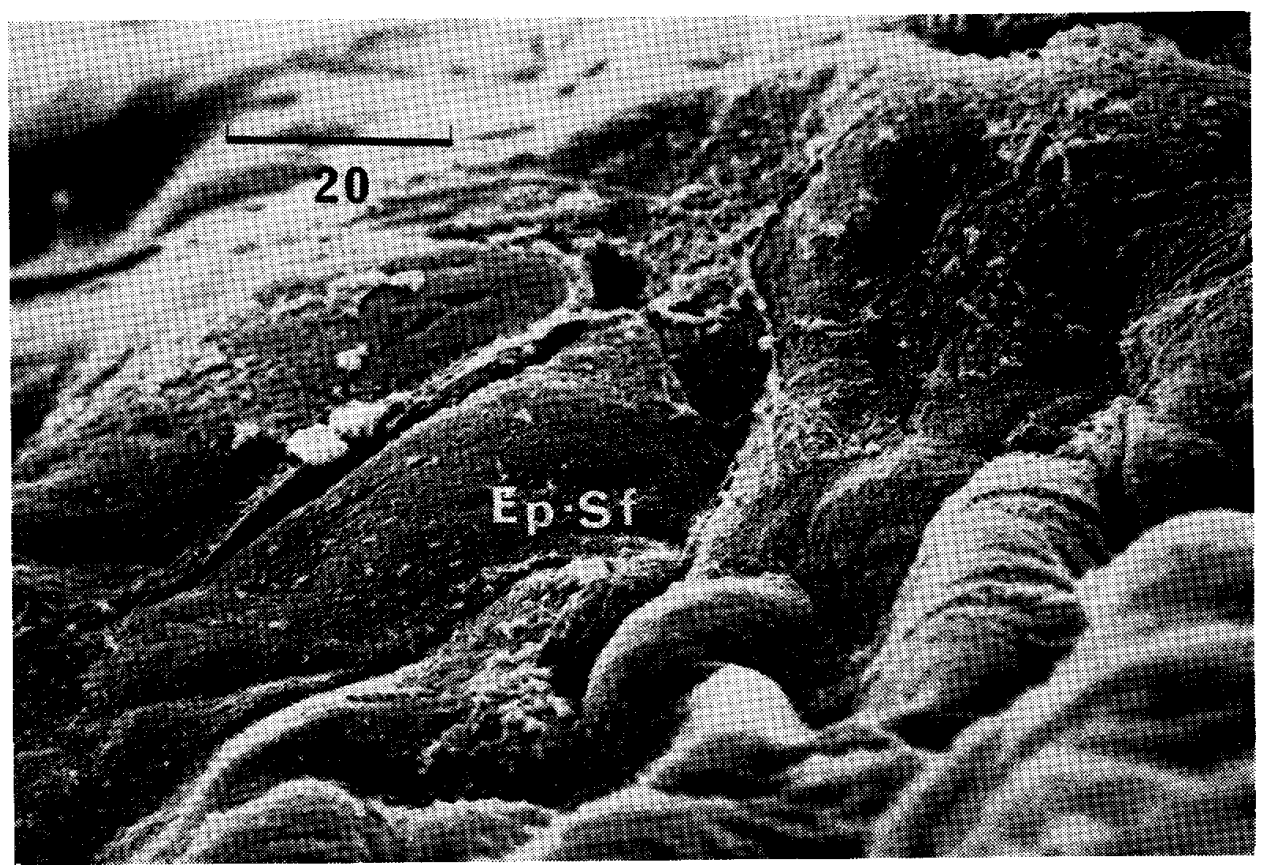

Fig. 7 濾胞性歯戝胞 (原始性霊胞) 走査電顕像

上皮細胞の遊離面は，ゆるい起伏を呈し，その表面は豊富な微小堤で覆わ
れている。
$\mathrm{Ep} \cdot \mathrm{Sf}$ : 上皮遊離面
$(\times 1,500)$ 


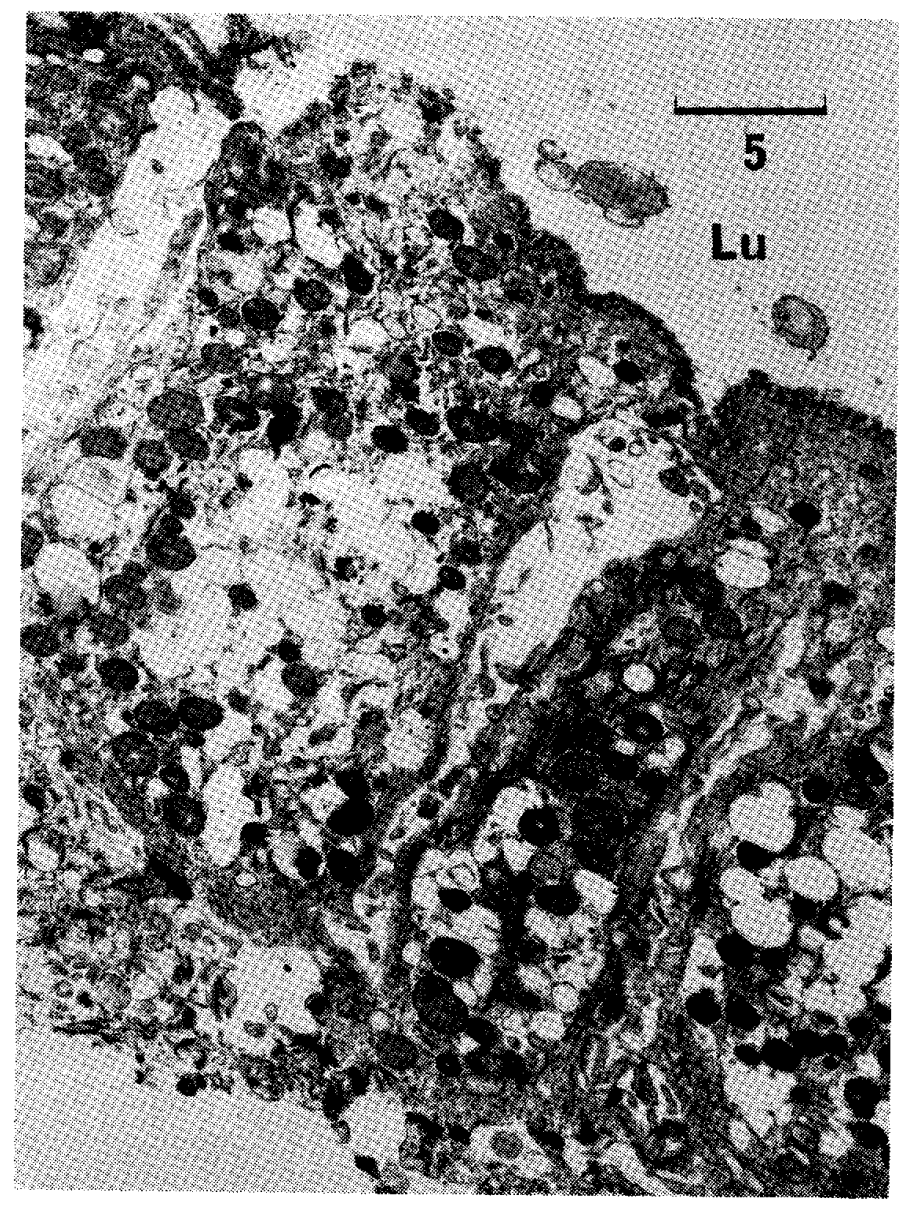

Fig. 8 含歯性襄胞上皮の透過電顕像

表層の上皮細胞は立方状を示し，多数のミトコンドリア と空胞様構造物が認められる. $(\times 4,000) \quad \mathrm{Lu}:$ 霊胞腔

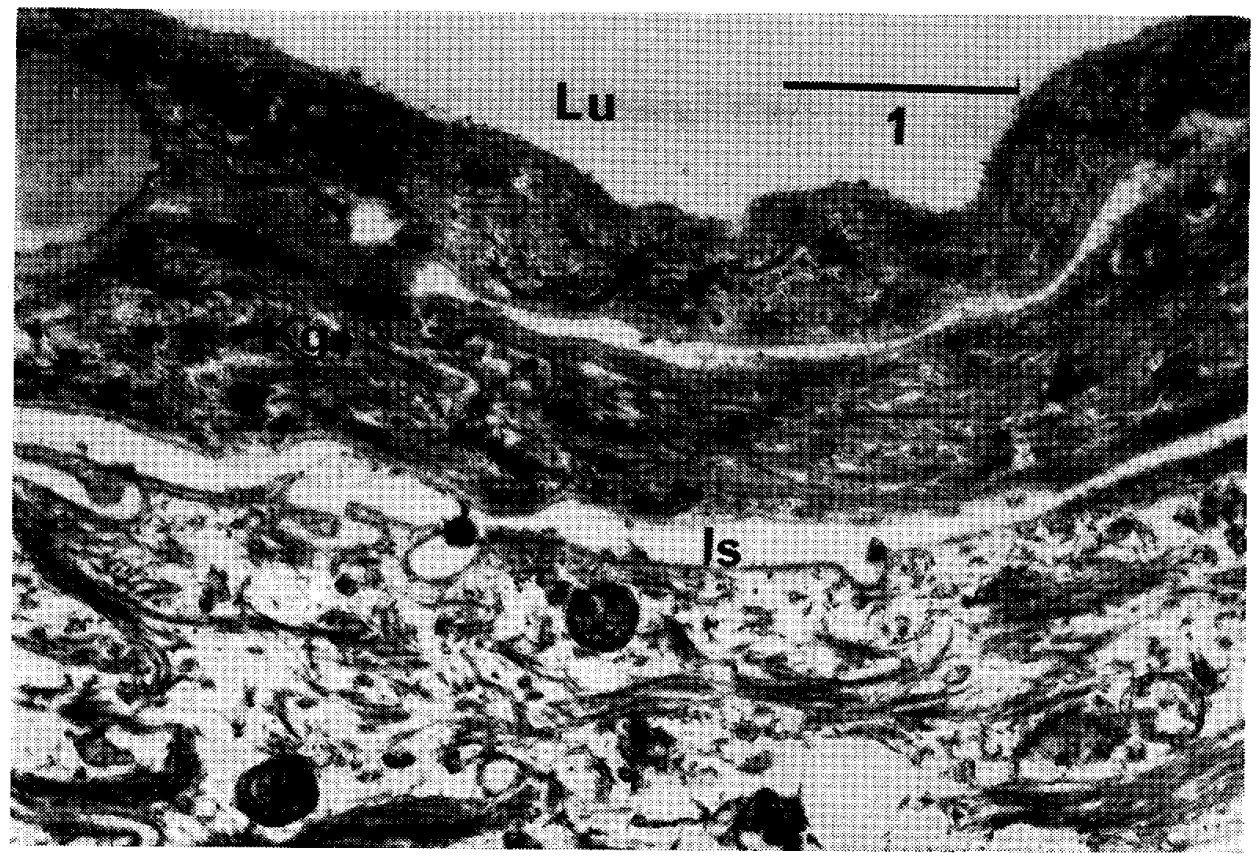

Fig. 9 原始性囊胞上皮の透過電顕像

上皮首は層板状配列を示す，中間首では明調を示すが，表首に進むに從い，卜 ノフィラメントが増生し，暗調を呈する。 $(\times 30,000)$
$\mathrm{Lu} ：$ 霊胞腔
$\mathrm{Kg}$ : ケラトヒアリン顆粒
Is : 細胞間空隙 


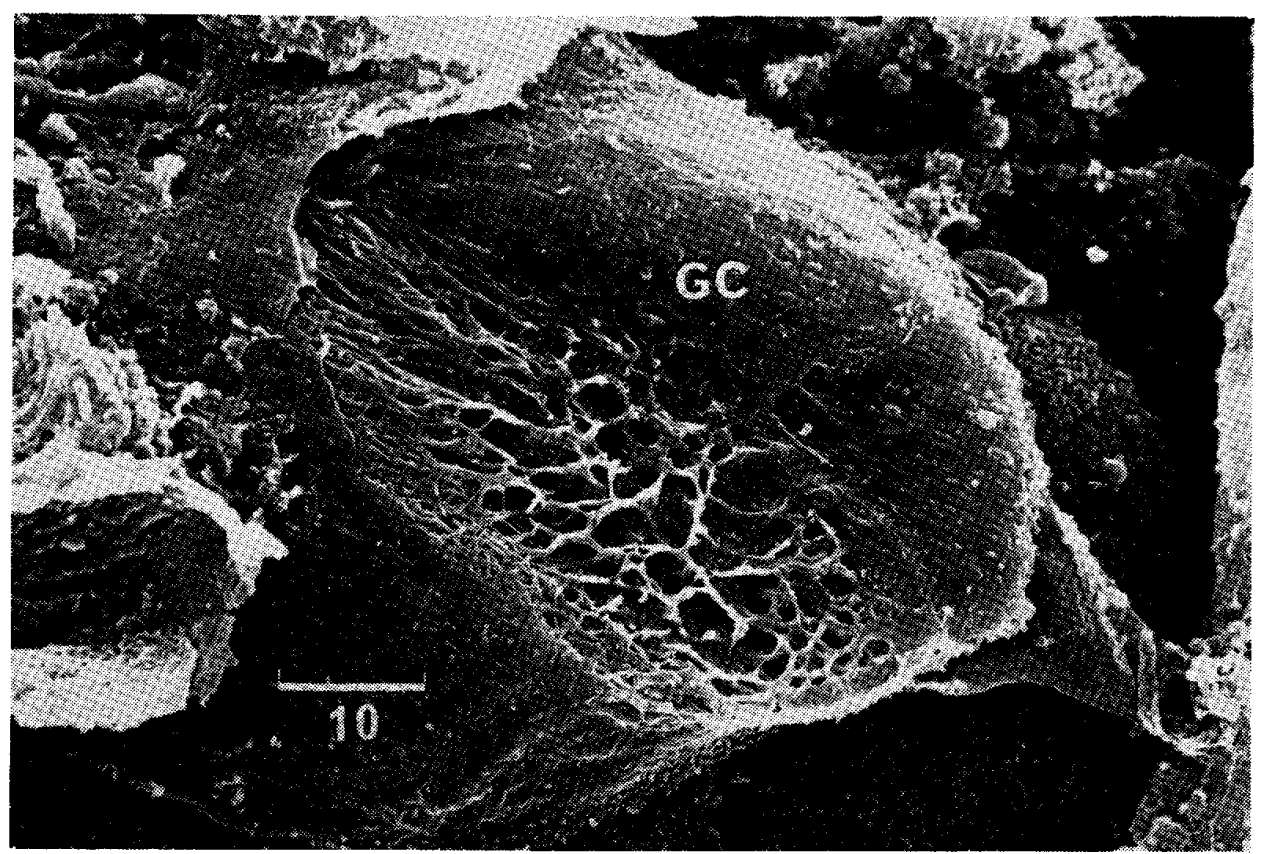

Fig. 10 石死化菌原性囊胞上皮断面の走査電顕像

Ghost cell はトノフィラメント束により区分けされた網目様模様を呈する. GC : Ghost cell $(\times 2,000)$

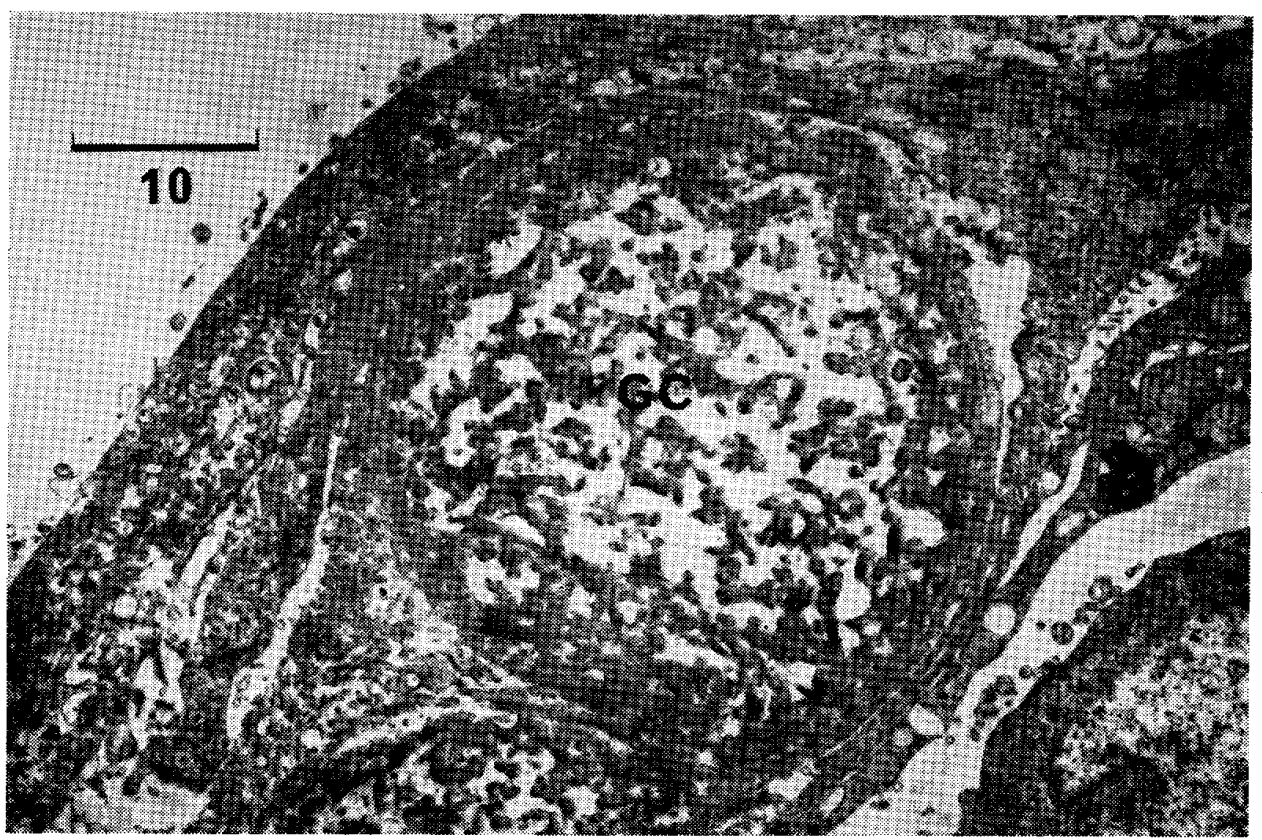

Fig. 11 石兏化蒾原性囊胞上皮の透過電顕像

Ghost cell (GC) を取り巻く細胞は扁平で, 細胞内小器官の発育は乏し い. 表層には微小突起（堤）が散見される. $(\times 2,500)$ 
る。

\section{2 . 走査電顕所見}

襄胞内壁最表面は全体的に波状を呈し, 細胞は大部分 が扁平で表層は平坦であるが，なかには棍棒状，半球状 に膨隆したものもある（Fig.12）。

拡大像では遊離表面は凹凸不整で粗造な鱗状模様を示 し微小堤も顆粒状を呈している. 部分的に分泌物と思わ れる雲状物質の付着も見られる（Fig．13）。

\section{3 . 透過電顕所見}

上皮の最表風細胞は，厚さ $1 \sim 2 \mu \mathrm{m}$ と比較的屚平で 胞体間質は高い電子密度を示し，ミトコンドリア，小胞 体は比較的上く発達している．下層の細胞とは樹枝状の 長い突起によって複雑に筷合しておう，遊離表面には $0.1 \sim 0.3 \mu \mathrm{m}$ の微絨毛の断面が多数観察される (Fig. 14).

\section{B . 下顎正中囊胞 \\ 1 . 光顕所見}

囊胞壁は外側の比較的密な線維性結合組織とその内側 は数層の重層扁平上皮からなる.前者では全体的に細胞 の存在は少なく，一部には円形細胞浸潤および血管の拡 張も認める。

\section{2 . 走査型電顕所見}

囊胞内壁表面は半球形に膨隆した大小の細胞が不規則 に敷石状に配列しており，内壁表面は全体的に波状を旺
しているが，一部には比較的大きくて多角形を是し，そ の中央部に核の存在を思わせる細胞も存在する. 敷石状 に配列した細胞は渑の甲羅を思わせる（Fig．15）。

遊離表面はヒダ状, 網目模様を呈する微小堤に被わ れ，一部にはそれら微小堤の尖端に蕾状の粘液を思わせ る付着物が認められる（Fig．16）。

\section{3 . 透過型電顕所見}

露胞上皮最表層細胞の細胞膜表面は断面で長さ約 0.2 $\sim 0.3 \mu \mathrm{m}$ の指状あるいは病状突出を示す微小堤を有し, 紐胞膜は二重構造のうち内細胞膜の肥厚が目立ってい る.胞体は不規則に走るトノフィラメントで涩たされて いる (Fig. 17).

\section{C. 鼻柬槽囊胞 \\ 1 . 光顕所見}

霣胞壁は $3 \sim 4$ 層の円柱上皮細胞に被われ，一部には 杯様細胞も見られる。また上皮下結合組織は比較的密な 線維性結合組織からなり，拡張した毛細血管が豊富に認 められる。しかし，炎症性細胞の浸潤は著明ではない。

2 . 走查電顕所見

囊胞上皮は，3〜4層の门柱上皮から構成されてい る. その基底層の細胞は立方形にして比較的大きく，規 則正しく配列している。細胞層の中には空洞化したもの もあるが，それは細胞内容が標本作製時に流出したもの であろう。また遊離側には杯様の陥凹を示すところがあ

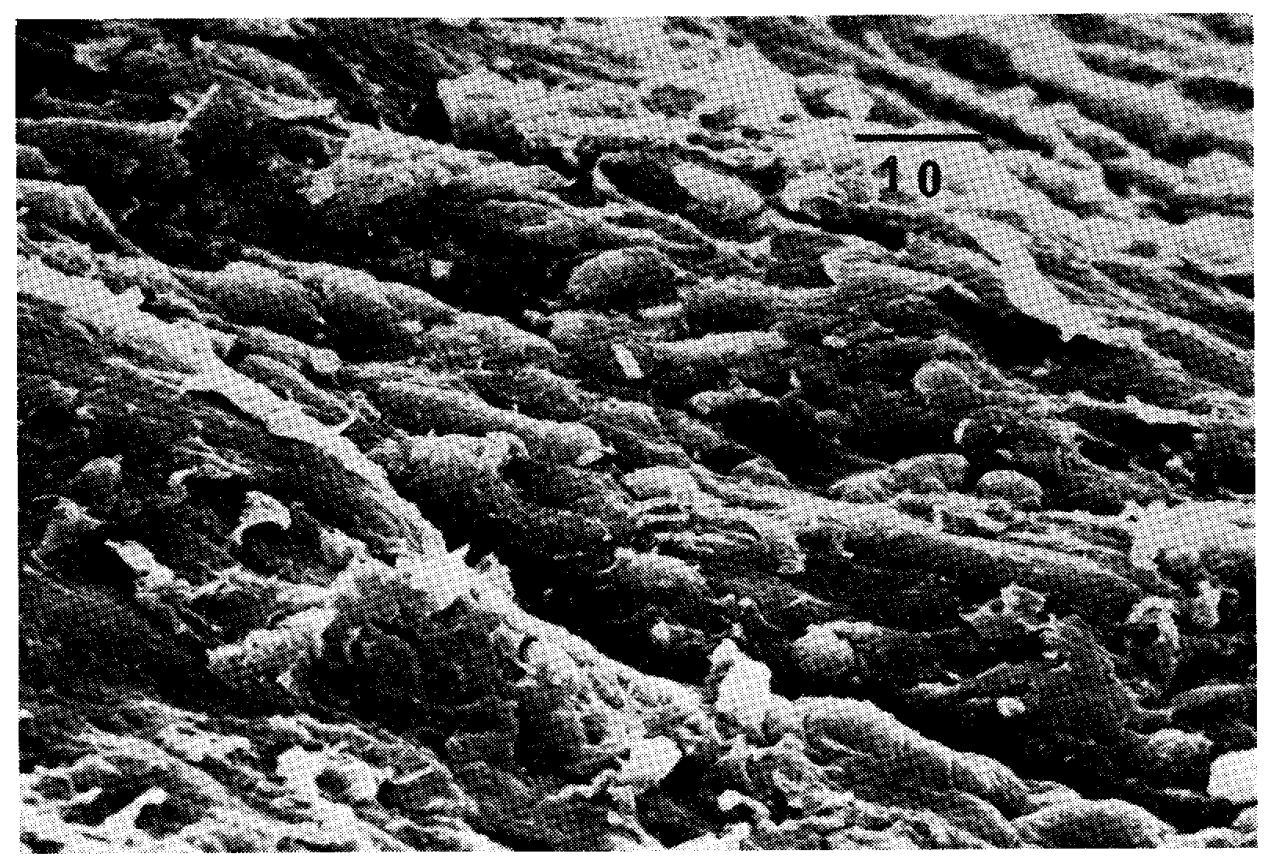

Fig. 12 上頢正中囊胞上皮の走查電顕像

表層細胞は全体として波状の走行を呈する. 部分的に剝離脱落中の細胞も 認められる。 $(\times 1,000)$ 


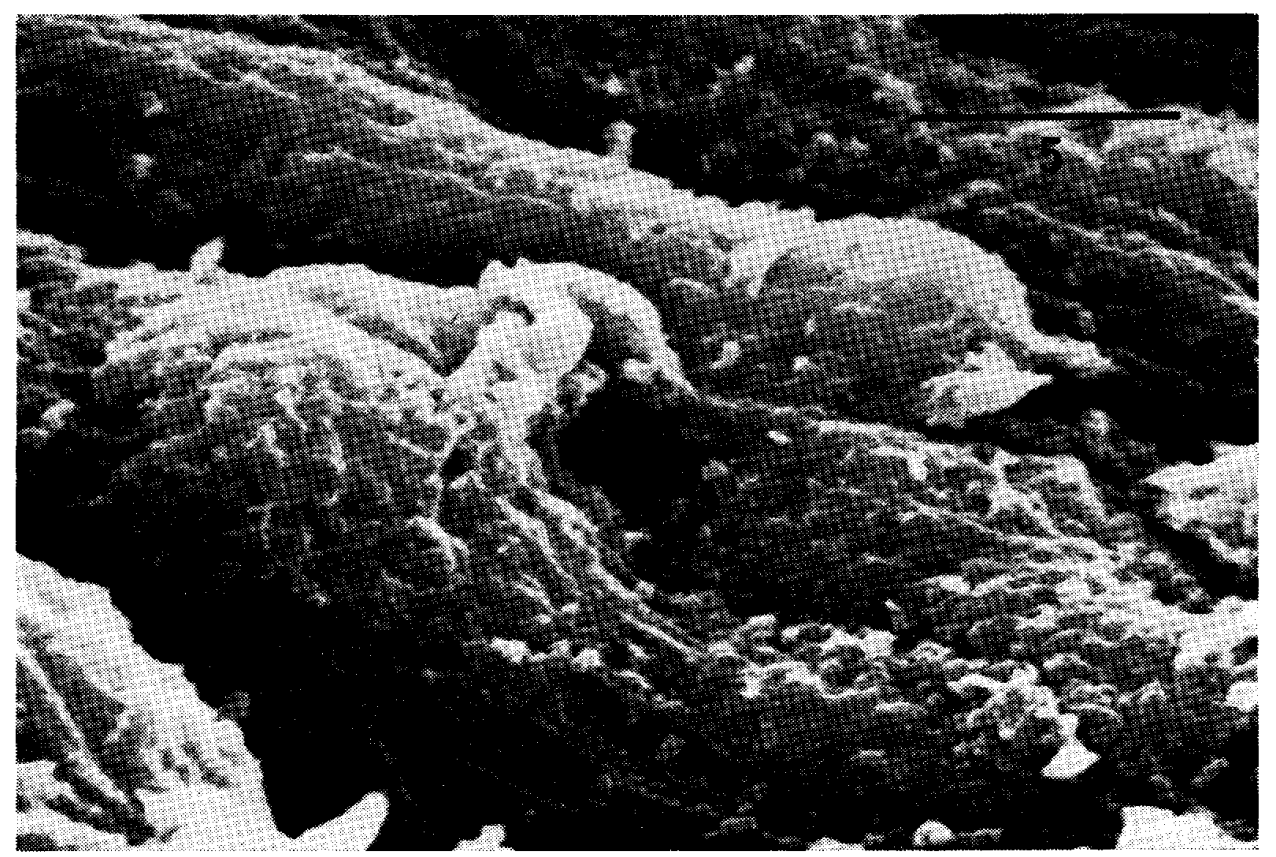

Fig. 13 上顎正中襄胞上皮表面の拡大走查電顕像

上皮は鱗状配列を示し，その遊離表面の微小堤は顆粒状を呈している.

$(\times 5,000)$

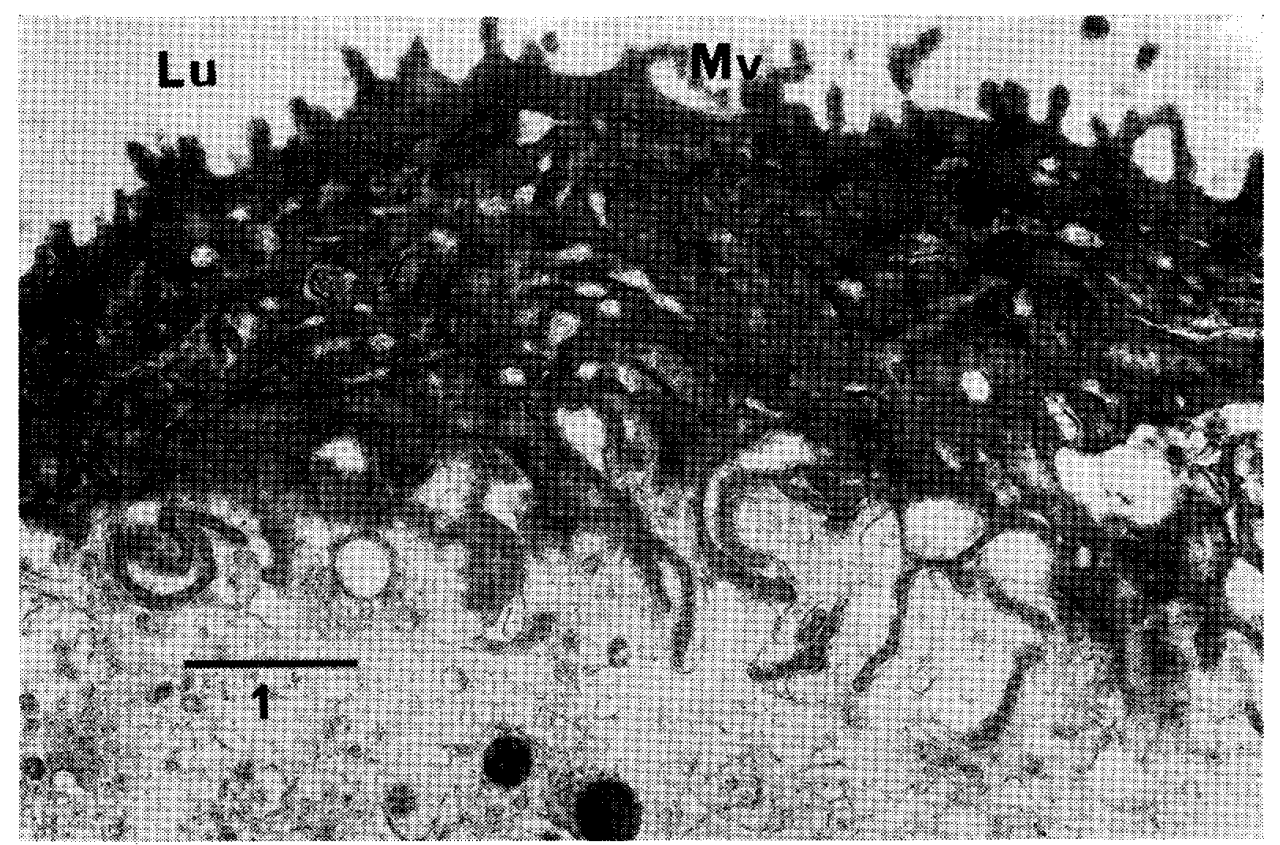

Fig. 14 上顟正中霊胞上皮の透過電顕像

表層細胞は比較的扁平で, 電子密度が高く, 遊離面は多数の微絨毛を備え
ている・
$(\times 10,000)$
$\mathrm{Mv}$ : 微緁毛
$\mathrm{Lu}:$ 霊胞腔 


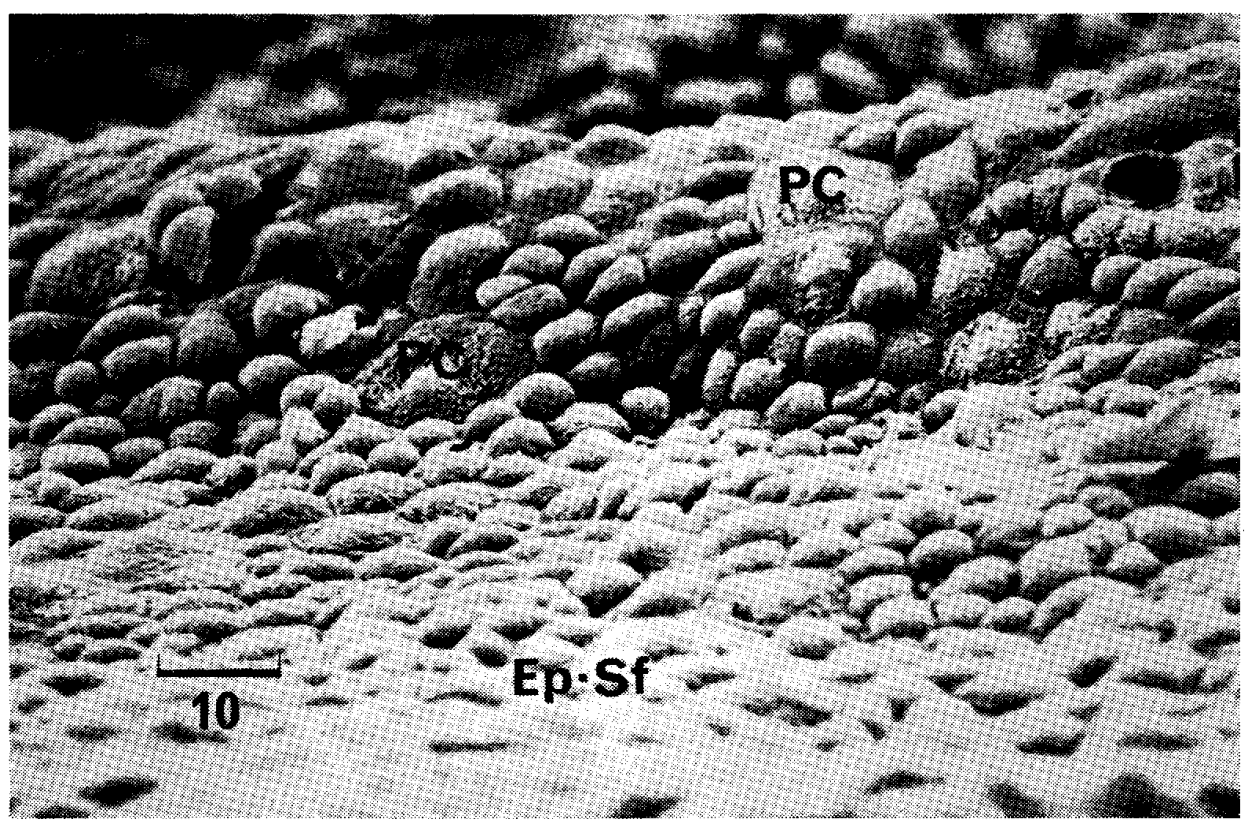

Fig. 15 下顎正中囊胞上皮の走査電顕像

表層の細胞の大部分は大小の半球形の隆起を示している．細胞の境界は比 較的に明膫である。 $\quad(\times 1,500)$

$\mathrm{Ep} \cdot \mathrm{Sf}$ : 上皮表面 $\mathrm{PC}:$ 多角形細胞

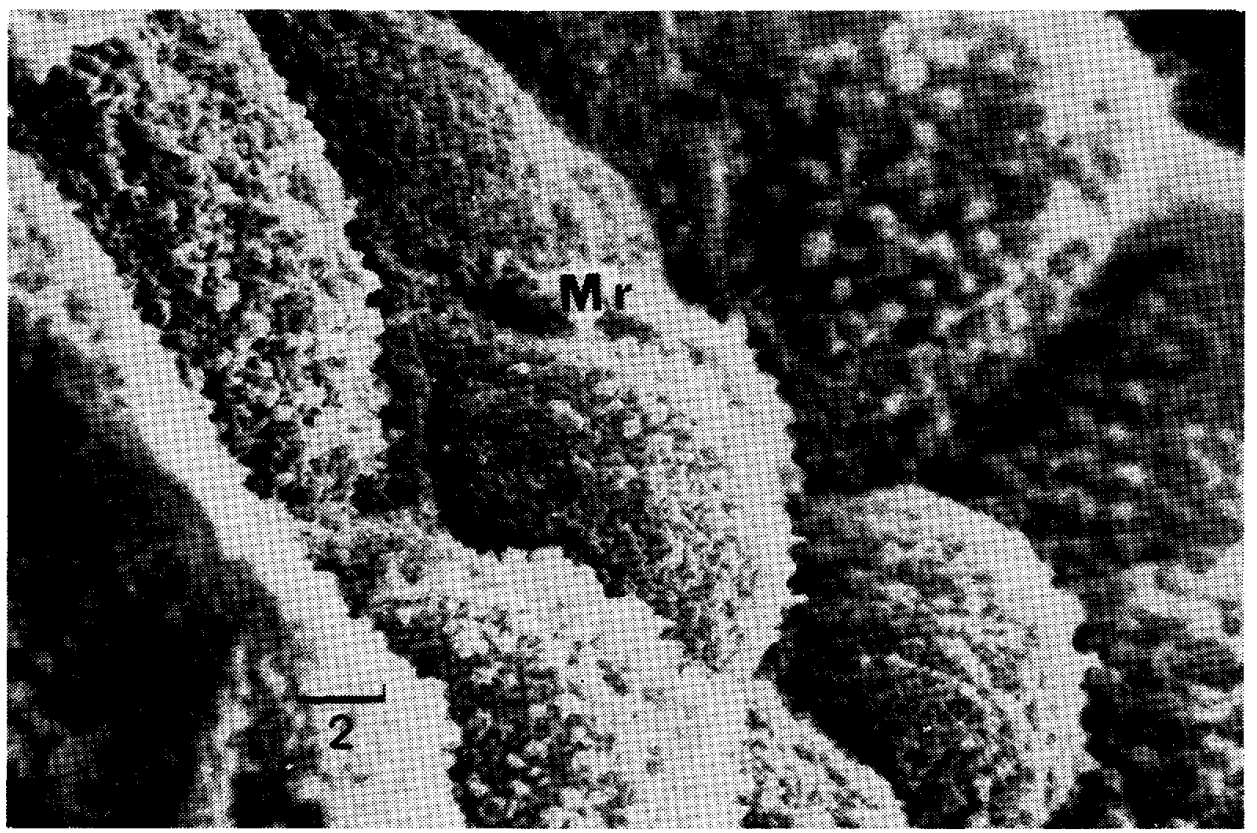

Fig. 16 下顎正中霊胞上皮の走查電顕拡大像

上皮の遊﨎表面は，七ダ状，網目模様の微小堤に覆われている.

$\mathrm{Mr}$ : 微小堤

$(\times 5,000)$ 


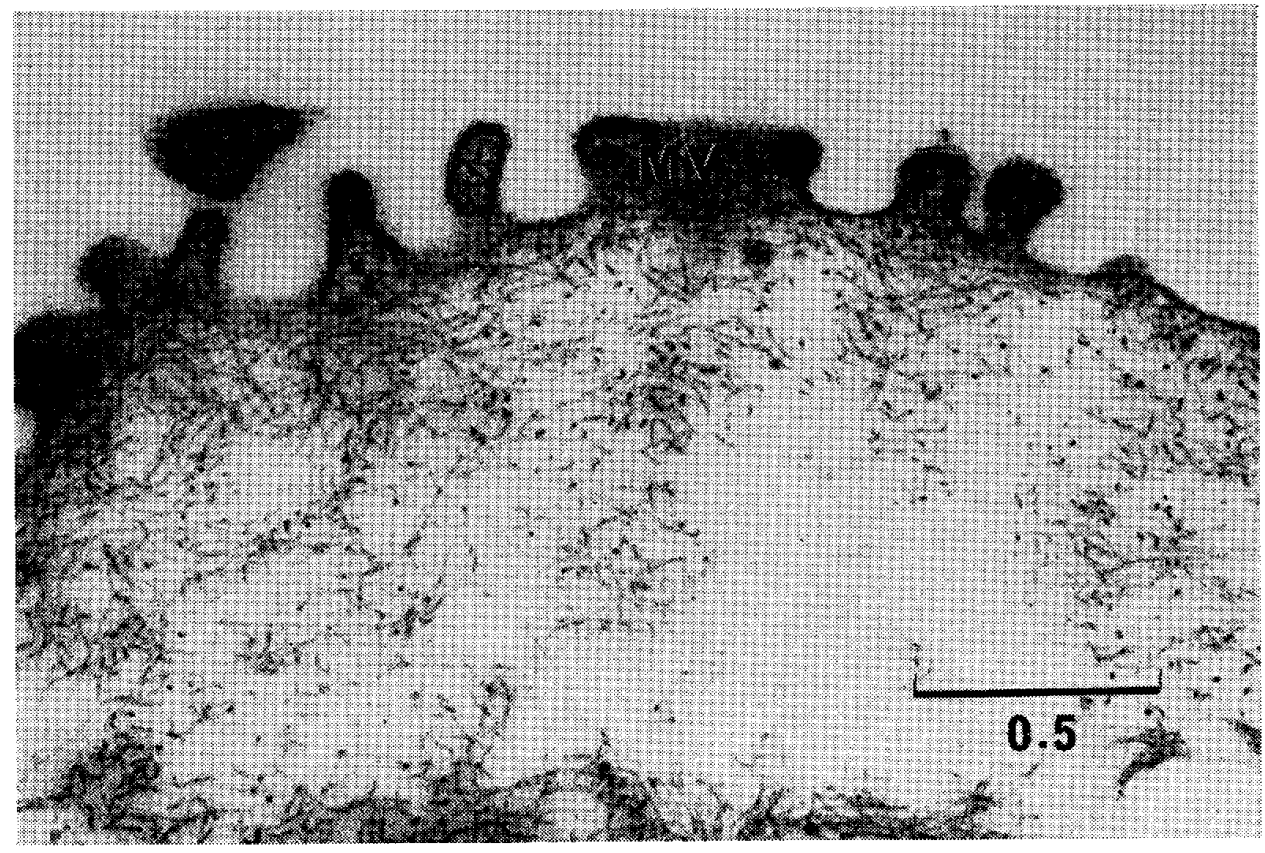

Fig. 17 下顎正中桽胞上皮の透過電顕像 上皮細胞の遊離表面は大小の旂状の微小堤を備え，胞体内にはトノフィラ メントが不規則に分布している。 $\quad(\times 60,000)$

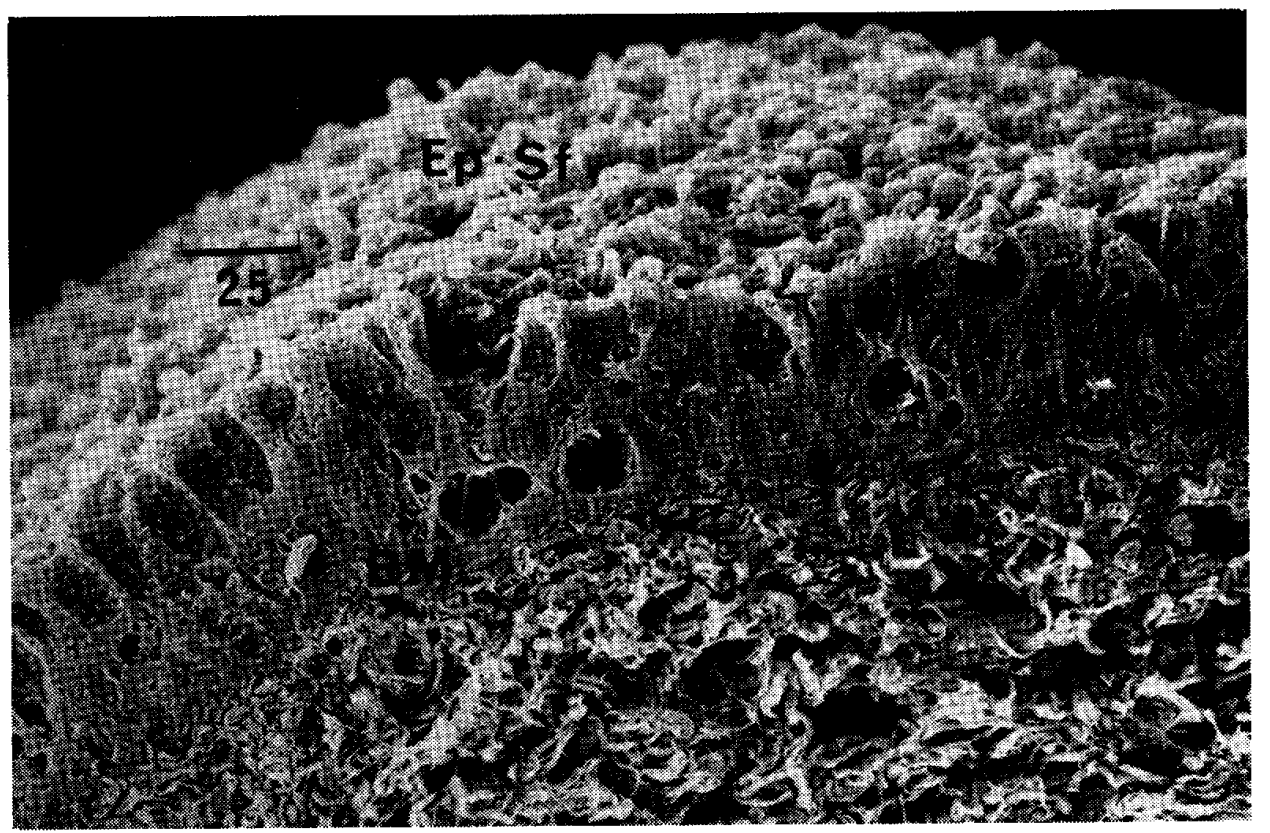

Fig. 18 鼻歯槽囊胞割断面の走査電顕像 襄胞壁は数層の円柱上皮細胞と結合組織から構成されている.

$$
\mathrm{Ep} \cdot \mathrm{Sf} \text { : 上皮表面 } \mathrm{BM} \text { ：基底膜 }
$$


り，その中には顆粒状構造物が見られることがある。恐 らく杯細胞の朤壊断面であろうと思われる (Fig. 18). 遊離表面の細胞間は深い裂溝様を示している．細胞の 表面は凹凹が著しく，時には粘液と思われる雲状物質の 付着も見られる（Fig. 19）。

\section{3 . 透過電顕所見}

最表層の細胞は円柱状を呈し，核も稽円形で基底側に 偏在している，細胞の上部には変性したミトコンドリ ア，Golgi 装置と思われる 空胞様構造が多く認められ る.隣接する細胞とは接着複合体で結合されている。遊 離表面は円頭様に膨隆している，一部には風船様の膨 隆，すなおちアポクリン様分泌物と思われる像も観察さ れる、遊離表面は比較的平坦で, 顆粒状の微小突起が散 在している (Fig. 20).

D . 鼻口蓋管囊胞

1 . 光顕所見

震胞内壁は重層扁平あるいは立方上皮に被われ，上皮 下結合組織は増殖した線維性結合組織から構成されてお り，そこには炎症性細胞の浸潤も認められる。

2 . 走査電顕所㫕

口蓋側上皮細胞層は扁平状を示し，比較的平坦で多角
形を呈し，敷石状に配列している．紐胞閒の境界は明瞭 である，一部には最表層細胞の落尿椂像も認められる。 細胞の遊離表面は多数の顆粒状に見える小突起を有して いる (Fig. 21).

鼻腔側の上皮細胞は丈が高く根棒状に突出し，從って 細胞間陌も深い，表面には微絨毛樣構造物もみられる (Fig . 22).

\section{3.透過電顕所見}

口蓋側上皮基底側の細胞は外形が扁平で，その配列は 比較的規則性を示している.内腔表面に進むに従い上皮 細胞は立方状を旺する。最表層細胞では核は基底側一偏 在し，隣接する細胞間は内腔へ近い部位では接着複合体 で結合している．遊離表面は比較的平坦で少数の微䄉毛 を有している (Fig. 23).

走査電顕におろいて棍棒状の膨隆を呈した細胞を透過電 顕でみると，その細胞は丈が高く，トノフィラメントの ほか高電子密度の顆粒様物, 空胞, ミトコンドリア，遊 離りボゾームを口蓋側上皮細胞と同じ様に含んでいる。 細胞の遊離表面には短かい微絨毛が散在性にみられる

(Fig . 24).

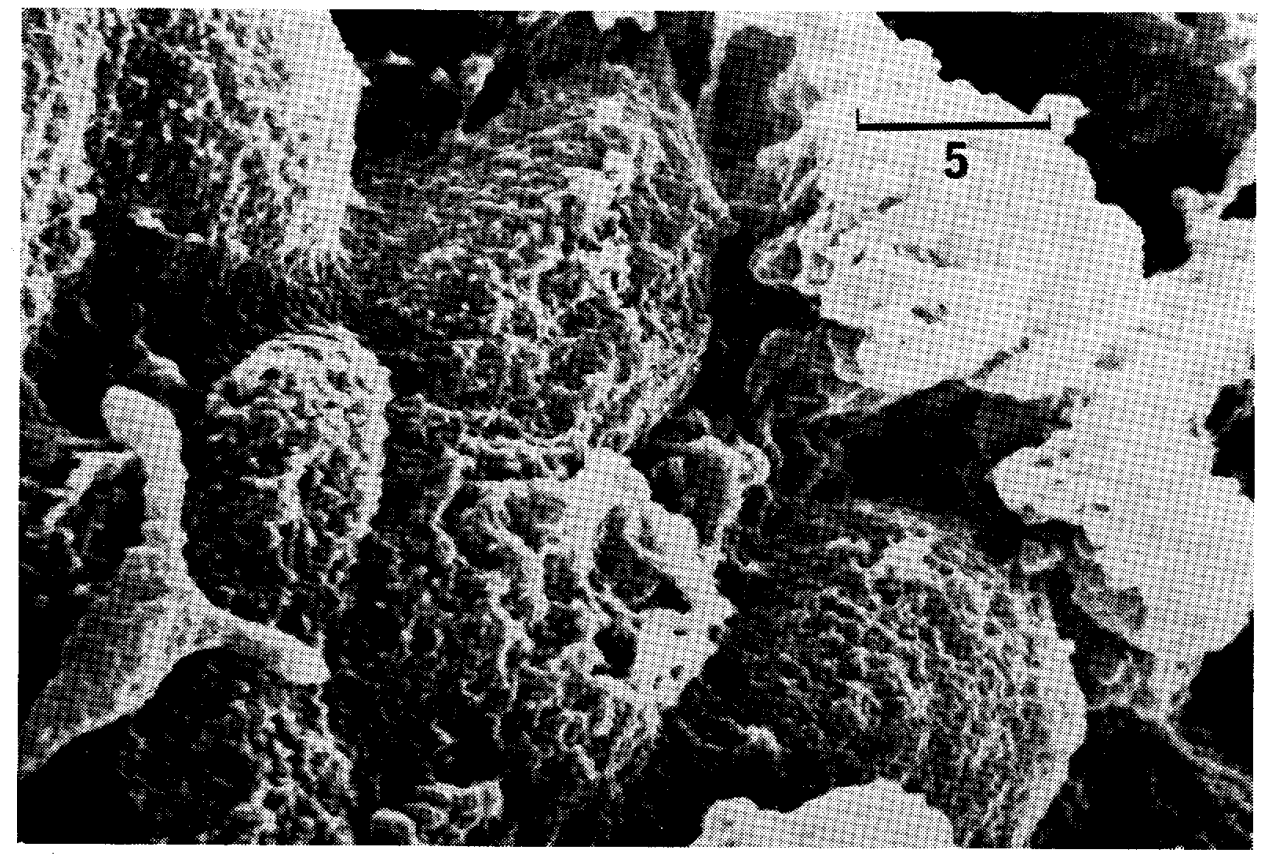

Fig. 19 鼻歯槽囊胞の走查電顕写真

細胞の表面は不規則な兔模様を呈し，ときには花キャベッ状の分测物の付

着も認められる。 $(\times 5,000)$ 


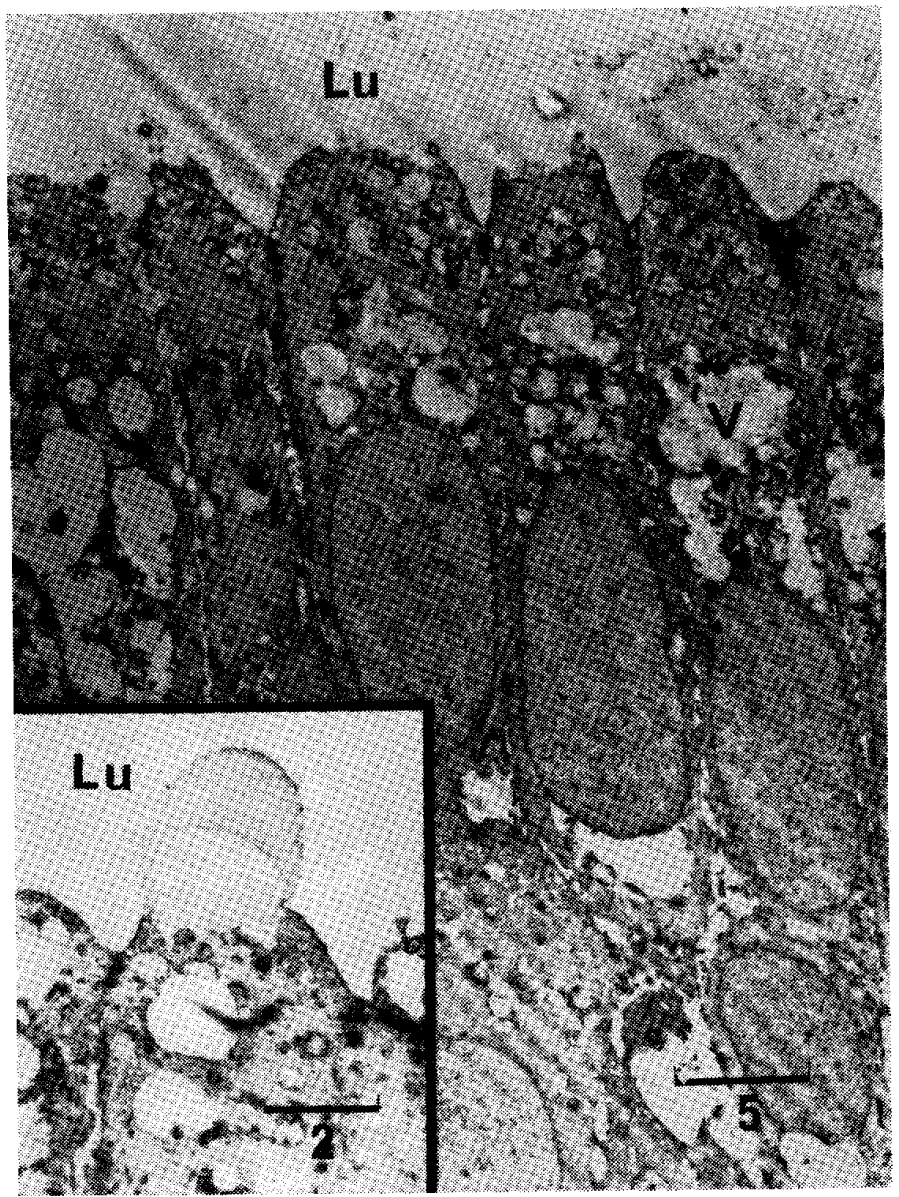

Fig. 20 鼻歯槽囊胞上皮の透過電顕写真

最表層の細胞は短冊状に配列し，核は基底側に偏在してい る・紐胞内には大小の空胞（粘液分泌物）がみられる・栛内 はアポクリン様瞦隆を示す. $\quad(\times 3,500)$

$\mathrm{Lu}:$ 霊胞腔 $\mathrm{V}$ : 空胞

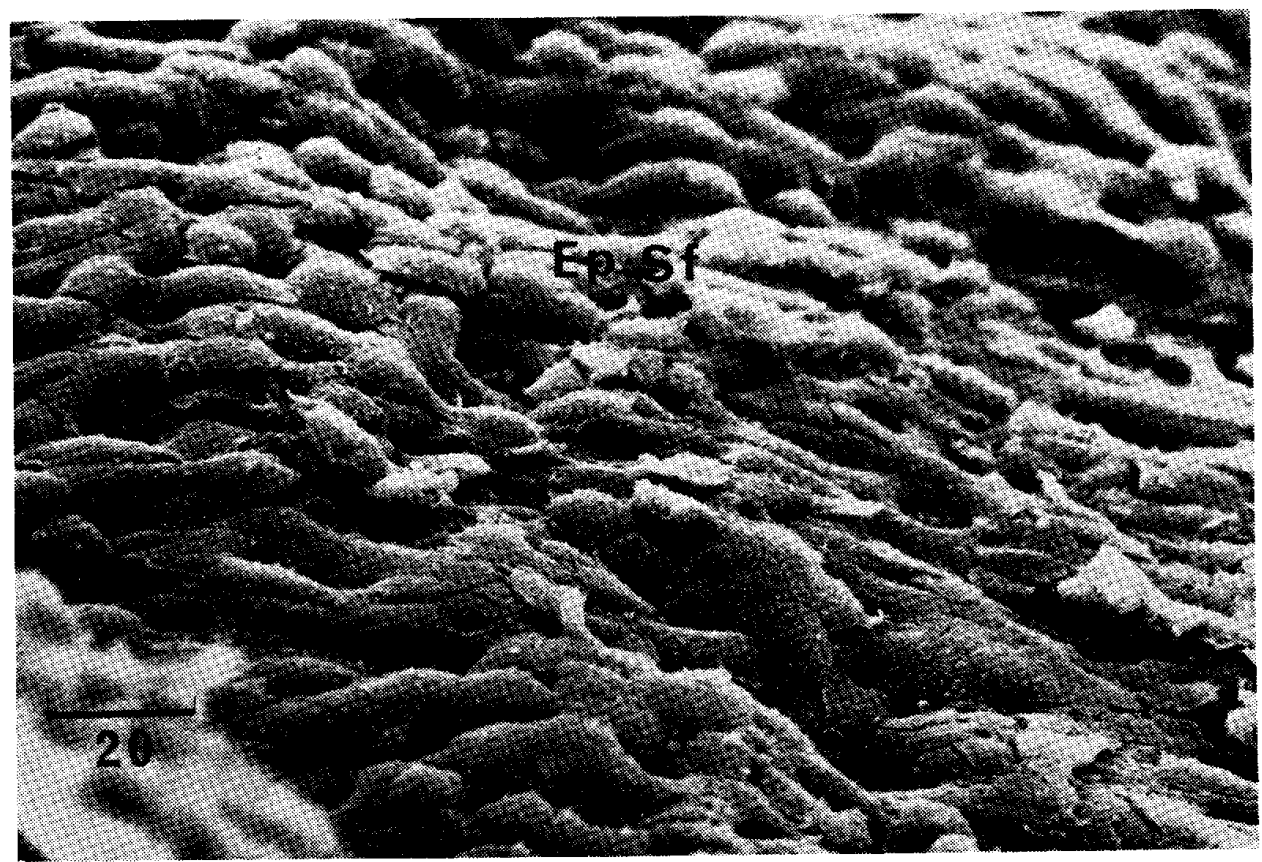

Fig. 21 鼼口蓋管囊胞上皮の走查電顥像

口蓋側上皮細胞は扁平で，敷石状配列を示し，表面には顆粒状突起を認める。 $\mathrm{Ep} \cdot \mathrm{Sf}$ : 上皮表面 


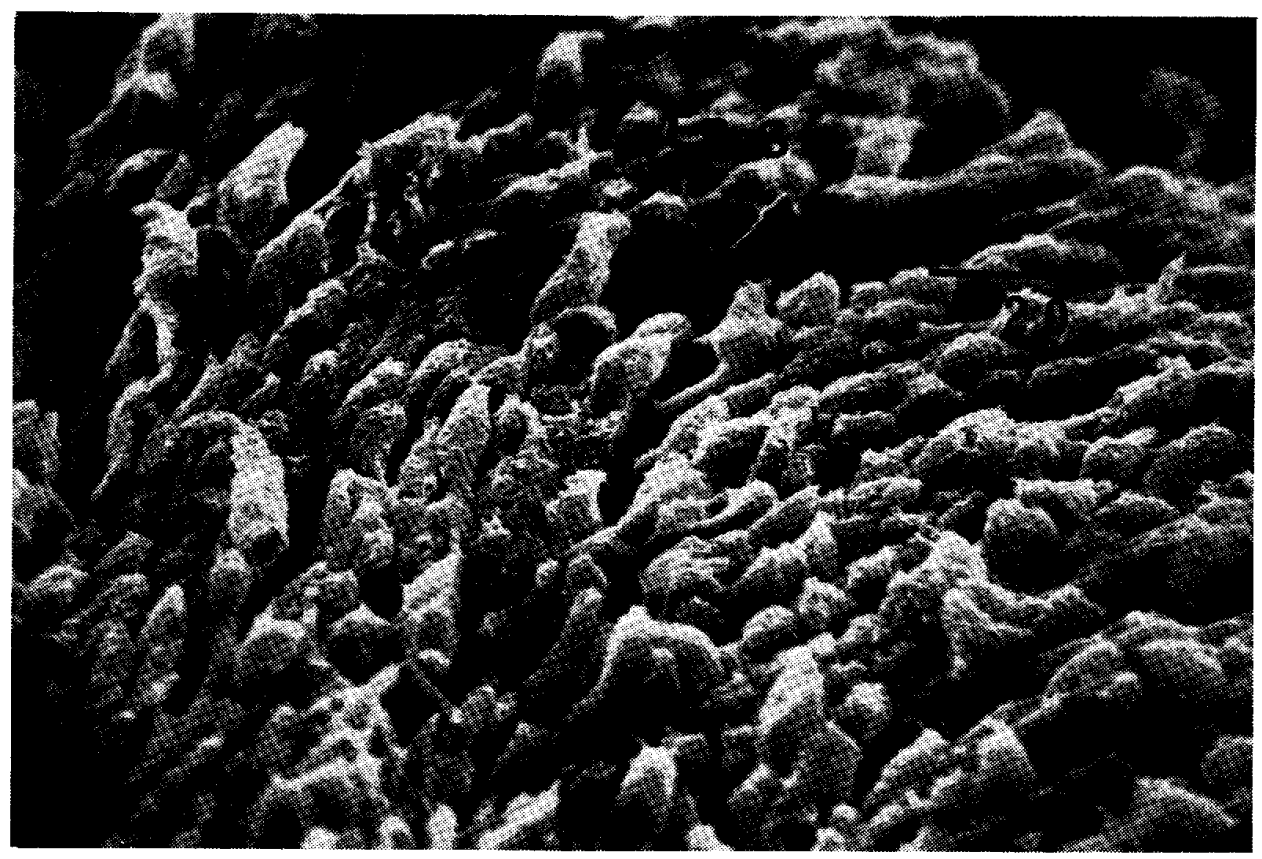

Fig. 22 鼻口蓋管穓胞の走查電顕像

鼻腔側上皮細胞は棒状を呈し，それら細胞の遊離面は微小堤様構造を呈し
ている。
$(\times 1,500)$
$\mathrm{Ep} \cdot \mathrm{Sf}$ : 上皮表面

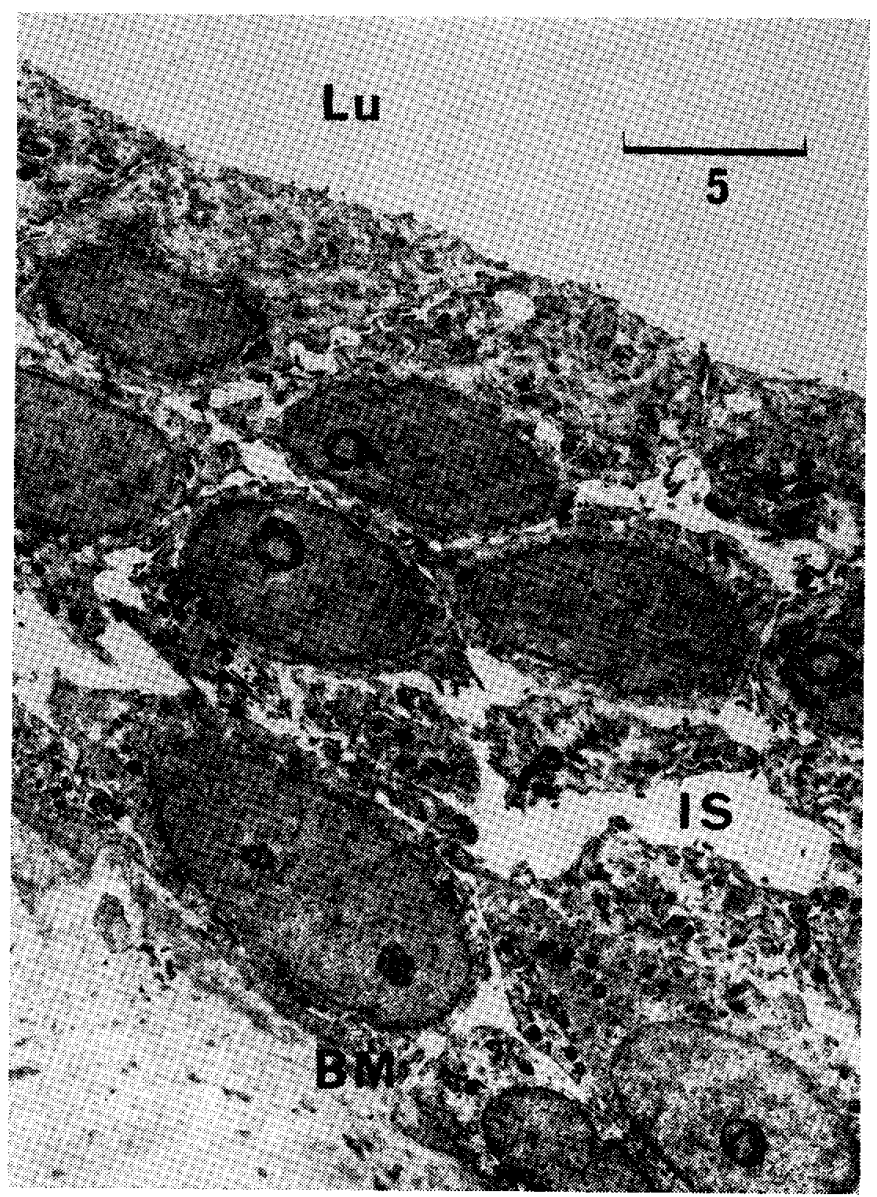

Fig. 23 鼻口蓋管囊胞の透電顕像

口蓋側上皮細胞首の配列は比較的規則性を示し，搌離表 面は平坦で小顆粒状突起を有する。
Lu：囊胞腔
$\mathrm{BM}$ : 基底膜
IS : 細胞間空腙 


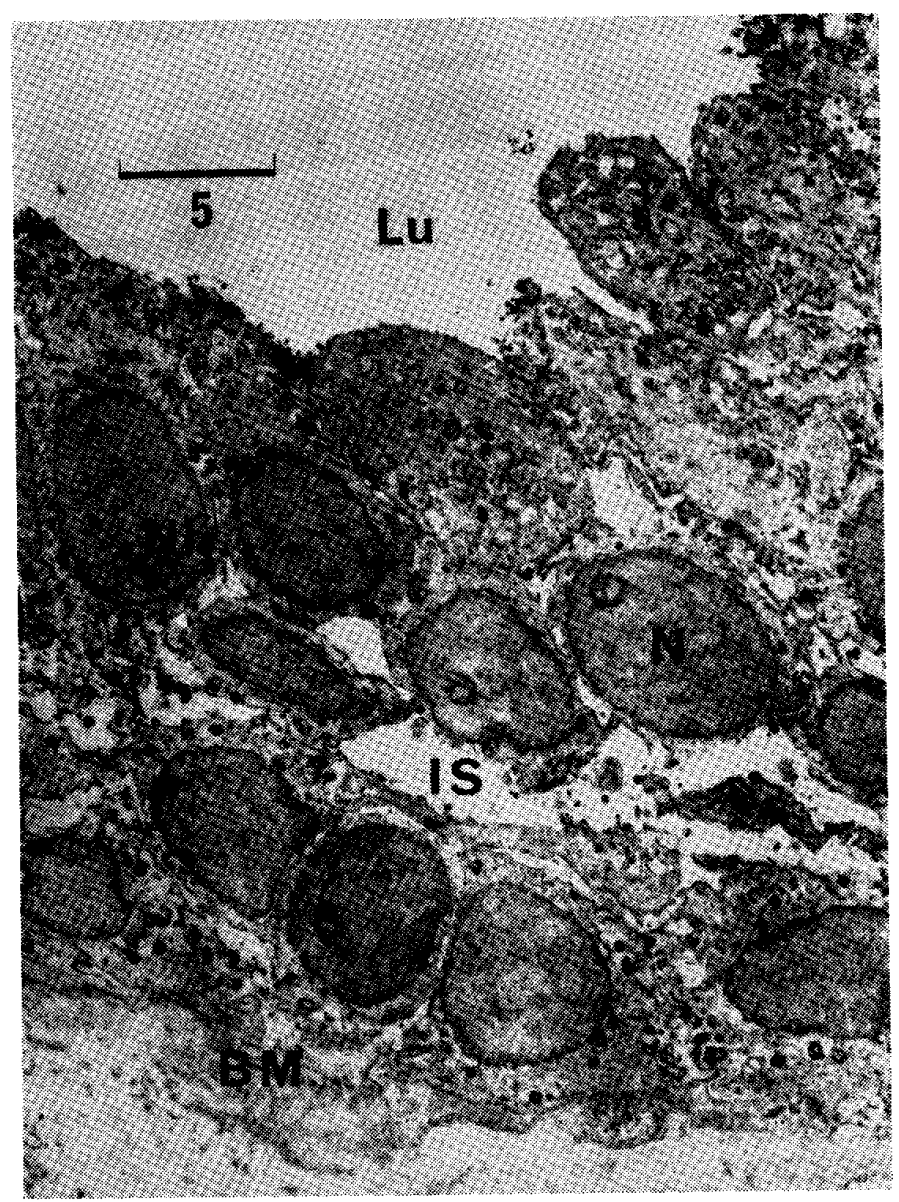

Fig. 24 鼻口蓋管霓胞の透過電顕像

鼻腔側の上皮細胞は短门柱状または立方状を呈し，遊離表面には小顆粒突 起を認める。 $(\times 5,000) \quad \mathrm{Lu}$ : 囊胞腔 IS : 細胞空隙 BM：基底膜

\section{考塞}

䅡, 口腔領域に発生する震胞性疾患は従来より種々の分 類がなされているが, 最近, 福島, 石木 $(1985)^{15)}$ は病 理組織学的診断に基づいた新分類法を提晶している.し

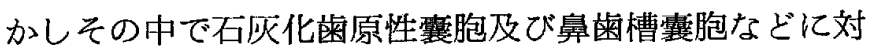
する区分には，なお不明確な問題もあるので，著者は33 症例の自験例を従来より提唱されている石川, 秋吉 (19 79）14'の分類に準拠して走查電顕ならびに透過電顕によ る侏用観察を試みた結果, 微小堤の形態, 遊離表面細胞 境界, 小孔, 角化の有無など若干の興味ある所見が得ら れたので各疾患別に比較検討を試みた。

I . 微小堤について

走査電顕では人の口腔粘膜表面を観察した Morgenroth $(1970)^{16)}$, Whittaker $(1971)^{17)}$, 松本ら (19 75) ${ }^{18}$, , 斉藤ら $(1975)^{191}$, 高木ら $\left(1976^{20}{ }^{\prime}, 1977^{21}\right)$, 丸谷ら $(1977)^{22}$ ，大神 $(1982)^{23}$ はヒダ状，うねり状, 網目模様の突起，または微絨毛などと呼称していたが，
現在では微小堤（マイクロリッシ）にほぼ統一されてお り，透過電顕で観察すると微䋐毛（マイクロビライ）様 に見えるのではないかと考えられている．微小堤の形態 学的分類は現在までに多く行なわれているが, 正常およ び病変粘膜の観察結果はいずれもその基準が一様でない のが現状のようである。しかし，今回著者が観察した症 例の中で歯根囊胞は永田 $(1981)^{11}$ 'の I 型, II 型, III 型, 高木 $(1977)^{21)}$ の I 型, II 型に, 含宩性襄胞では永 田（1981）11）の II 型， III 型に，原始性囊胞は $\mathrm{N} \sim \mathrm{V}$ 型 に，石灰化雨原性囊胞は原始性囊胞に類似した所見が得 られた。一方, 非霜原性囊胞の上罰正中震胞は永田（19

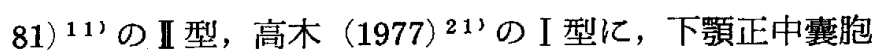
は永田（1981）11のN型，高木 $(1977)^{211}$ のII型に類似 し，鼻歯槽囊胞は永田（1981） ${ }^{11}$ のV 型，高木（1977） 21)のV 型に, 鼻口蓋管囊胞の口蓋側に近い部分は永田 (1981 $)^{11}$ ，高木 $(1977)^{21} の \mathbb{I}$ 型, 鼻腔側に近い部分 は永田 $(1981)^{11}$ ，高木（1977）21'のV型に一致した所 見が得られた。 
上述の如く，著者の自験例でも微小堤には各囊胞間に おいて著しい形態学的な差が見られた。てての原因として は発生由来が同じ外胚葉にもかかわらず，外的要因の付

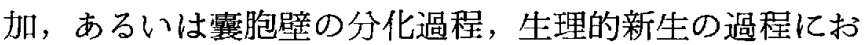
ける変化さらに微小堤の機能面から膜表面の流動性, Olson ら (1973) 24) が報告した表面積拡大による 細胞 代謝の元進, Hughes ら $(1970)^{25)}$ ， Sperry ら (19 76) ${ }^{26)}$ が述べている粘液, 水分の調整装置としての役割 などが挙げられよう．自験例の結果から炎症性刺激の強 弱が微小堤の形態に与える影響は甚大であることは勿 論, 疾患の発生部位, 角化の状態々程度, 経過, 年秢, 性別もこれらの変化に関与するものと想定される．乙の ことから微小堤の形態学的構造の変化の把握が敏胞の発 病期間，諸症状の接点，あるいは臨床的に治療方針々術 後の予見等を知り得る手掛りになるのではないかと考え られる。

\section{II . 遊離表面細胞境界について}

松本ら (1975) ${ }^{181}$ ，杉原ら (1977 ${ }^{271}$ の正常口腔粘膜 の報告でも部位により若干の差異はあるが，一般的には 細胞境界は明瞭であると述べている。しかし，病変によ ってはその境界は明瞭であると述べるものと，また不明 膫であるという報告もみられる。䨳胞上皮については山 下ら $(1980)^{281}$ ，永田 $(1981)^{111}$ ，若江 (1982) ${ }^{121}$ の報 告があり，彼らによれば疾患により若干の差異が示さ れ，永田 (1981) ${ }^{11}$ は炎症の強弱の度合いにより細胞配 列の構築は乱れやすく，境界も不明暸であったと記載し ている。

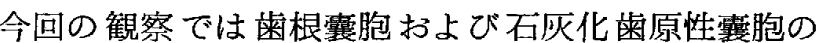
Ghost cell の存型する霊胞壁の 細胞境界が不明瞭であ ったが，てれは歯根霊胞では従来より述べられている慢 性炎症性刺激による囊胞形成ならびに発育に起因し，石 灭化歯原性囊胞に於いては急激に加わった異常な刺激に よる上皮細胞の膨化のためと考えられる。

III. 小孔について

囊胞性疾患の遊離表面境界部に観察された小孔につい て走查電顕的には現在まで文献を啮猙し得た範囲での報

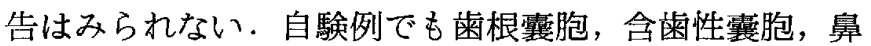
口蓋管襄胞に限って認められた。

これらの小孔には閒葉系由来と思われる細胞の存在が 認められたが，著者はこれらの小孔は浸潤細胞の通路の 他に賴胞の発育, 増大に影響を及ぼし,さらに上皮細胞 の機能に適応した状態を保ち, 垔胞組織の安定度を暗示 している調節装置と考えている. また, 当該箅所は透過 電顕で拡大した細胞間腺に相当する部分としてFrithiof

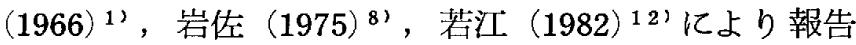
されているが，細胞間陌について彼らは霊胞增大の一因 子とされている浸透圧の調節に関与するものと推察して いる.乙れらの拡大した細胞間陌は，三次元的な形態レ ベルでは小孔に相当し，したがって上皮細胞の変性およ び浸透圧の調節装置の役割も果たす可能性があると考え た。

IV. 分泌物について

襄胞内面は通常重層嵋平上皮で被覆されているが，な

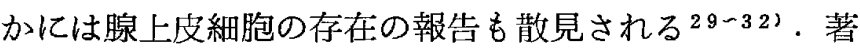
者の場合では上述の所見と類似する症例として歯根囊 胞, 滤胞性蒾囊胞（含歯性），鼻口蓋管囊胞，鼻歯槽囊 胞があげられる．尾関 $(1983)^{32}$ は腺上皮の存在は角化 傾向を示す細胞には認められなかったと報告しているが 著者の場合も同様であった．分必样物質についての報告

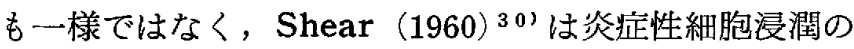
乏しい症例に粘液細胞や線毛細胞が多く出現したと述 べ，乙れは尾関 $(1983)^{32}$ ') 1 型あるいは 2 型に相当す る所見であり，当症例の雪根囊胞は尾関 $(1983)^{32)}$ の 3 型，4 型に該当するように思われる．なお，歯根桽胞は 臨床病理学的に従来より inflammatory type の䡩胞 として位置づけられているが，著者も炎症性刺激の強弱 が分珔能に影響を及ぼしているのではないかと想定して いる。

透過電顕所見で著者は含雪性囊胞の細胞胞体内に分泌 顆粒を含んだ細胞を認めたが，乙れは尾関 $(1983)^{322} の$ Goblet cell type に相当するものと思われた。なお， 本囊胞は菌原性由来で腺上皮の存在は通常見られない。 しかしながら Goblet cell の迷入および化生説も陧え られているところであり，Goblet cell が見られてす不 思議ではない，線毛上皮の存在について著者は上靧囊胞 では呼吸器に近いという解剖学的位置から出現も有り得 ると考えられるが,下顎襄胞では Browne ら (1972) ${ }^{311}$ が述べた重層扁平上皮の化生説が妥当のように思われ る。また，鼻霜槽囊胞症例の観察でアポクリン様分泌を 示唆する所見が得られたが，てれは尾関 $(1983)^{321}$ の 3 型に類似している。いずれにせよ霊胞の発生と拡大につ いて不明な点も多いが，その宿主を取り围む環境に合目 的々であり，その変化に応じた形態示をすものと思われ る。

\section{$V$ ，角化について}

上皮細胞の角化機構については従来より光顕的, 電顕 的および組織化学的研究が多く行なわれ，松本ら (1975) 18)，杉原ら (1977) ${ }^{27)}$ はヒトの正常口腔粘膜において 
も年㱓，性別，部位により角化の形態に差異がみられた と述べている．また，角化囊胞を観察した岩佐 $(1975)^{81}$ によれば菌原性襄胞の中では無歯性濾胞性歯囊胞に角化 層は多く見られたと報告し，管ら $(1982)^{\left.3{ }^{3}\right)}$ は歯原性角化 囊胞では全症例共角化の形成を認めたが石灰化歯原性囊 胞では典型的な角化像は得られなかったと述べている。 著者の場合では濾胞性歯囊胞（原始性）および上顎正中 囊胞にのみ角化が みられ, 岩佐 ${ }^{8}$ ，管ら ${ }^{331}$ と同様の所 見が得られた。従来より上堮正中囊胞の角化についての 報告は少ない上うであるが，著者は本症例については襄 胞の反応性変化の結果によるものではないかと考えた い. このように歯原性および非歯原性露胞に於いて角化 像抢よび非角化像が存在することについて，主として口 腔粘膜の病的角化を観察した小野 $(1970)^{34)}$ は, 角化首 での keratin pattern 生成過程の差によるもので， そ の程度はさまざまであり，それに伴ない形態学的にも多 様な所見を示すためと述べている，走査電顕による微紐 構築学的にも, また透過電顕による微細構造学的にも正 常の口腔粘膜および病的粘膜の角化機構が異なるのは上 述の報告からも当然のととと考えられ，本症例の場合同 一疾患仿於いても角化，非角化を呈する上皮組織像を観 察したことから，その原因は一元的ではない様に思われ た。

今回，著者が観察した33例の䁚胞上皮細胞の遊離表面 構造を三次元的に観察し，それに加えて同一部位を透過 型電顕で併用観察した結果, マイクロリッシの形態, 紏 胞の表面境界，分泌様物の有無および角化状況が各種囊 胞により異なった所見が得られた，囊胞性疾患がこの様 に多样な所見を示すてとについては未だ不明な点が多 く，今後はさらに症例を追加し検討を試みる所存であ る。

\section{結論}

ヒトの顎，口腔領域に発生した歯原性 霊胞（歯根囊

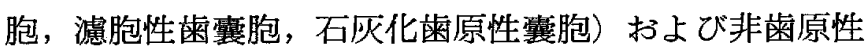

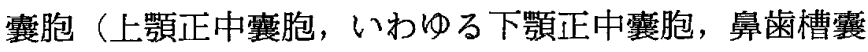
胞，鼻口蓋管䪄胞）計33症例の上皮構造を電顕的に観察 し次の結果を得た。

I . 歯原性囊胞

A. 荬根囊胞

襄胞上皮細胞は多角形で石畳状の配列を示し，表面は 不規則な模様の微小堤, 部位によっては比較的長い微絨 毛によって覆われる．ての上皮で特徴的な事は上皮細胞 間に円形または半月状の小孔が頻繁に見られ，その間隍
を間葉系と思われる細胞が通過している事である・表層 上皮細胞は紐胞内小器宫に乏しく，多くの空胞を含ん でいる。

\section{B . 濾胞性歯囊胞}

\section{1. 含蒾性賈胞}

上皮細胞の遊離表面形態はほとんどが不規則な半球状 にして，それらの境界は明瞭である。それら細胞の表面 は網目模様の低い微小堤に被覆されている，上皮細胞の 一部には円形の間隙があり，その中に間葉系と思われる 細胞を容れている．切片で観察すると，最表層の上皮細 胞は立方状を示し，ミトコンドリアや胞空樣構造物が著 明である．隣接する細胞間はデスモゾームによる陌合結 合様式を呈している。

\section{2. 原始性䙵胞}

扁平化した最表層細胞の細胞膜は肥厚傾向を示し, 遊 離表面の細胞間境界は龟甲状の敷石配列を呈する－個々 の上皮細胞表面は網目 模椂の低い微小堤に覆われてい る. これら上皮細胞では細胞内小器官の発達が悪く, ト ノフィラメント束に満たされている.

\section{C. 石灰化歯原性囊胞}

本疾患の特徴である Ghost cell の走査像では多数の 線維様構造物が不規則に走行し，からみ合い網目模様を 呈しており, 透過像では角質層の上皮細胞は扁平化が著 しく, 層板椂配列を示し, その遊離表面は比較的平坦で 丈の低い顆粒状の微小堤に覆われていた。また，胞体内 小器官はほとんど詡めず，トノフィラメント束に満たさ れている。

I . 非歯原性囊胞

A . 上䫟正中囊胞

霊胞最内壁を形成する上皮細胞は扁平で，その表面は 凹凸不整にして鱗状模様を呈し，やや大粒の顆粒状に配 列した微小堤（高さ $0.1 \sim 0.3 \mu \mathrm{m}$ ）に覆われている.下 層の細胞とは複雑な樹枝状の䈈合をしている，最上層の 上皮細胞は電子密度が高く，ミトコンドリア，粗面小胞 体に富んでいる。

\section{B. 下顎正中囊胞}

最表層上皮細胞は不規則な半球形にして，敷石状に配 列し，それらの境界は堤防状をなして少し高まってい る。それらの遊離表面は網目様, 陥凹様構造を呈する微

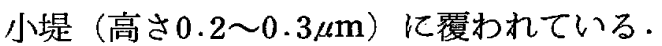

\section{C. 鼻歯槽囊胞}

最表層上皮細胞は円柱状を呈し，核は基底側に偏在 し, 細胞内小器官の発達は良好である. それらの遊離表 面は円頭様膨隆を呈し，七ダ状の微小堤に被われてい 
る・

\section{D ． 鼻口蓋管囊胞}

最表層上皮細胞は円柱状あるいは立方状を呈し，基底 側に核を有し, 細胞内小器官の発達は良好である。それ ら細胞の遊離面は敷石をつめたように配列するとてろゃ 四凸不整に配列するところなどが見られるが，全体的に は顆粒状あるいは七父状の微小堤に被われている。

謝 辞

稿を終わるにあたり，御愁篤な御指導と御校閲を賜 わった恩師冨岡德也教授に深甚なる感謝の意を表わしま
ఫ.

また，種々，適切なる御助言ならびに御校閲を賜わっ た九州柬科大学第 1 口腔外科学講座, 山田長敬教授なら びに久留米大学医学部第 2 解剖学講坐, 村上正浩教授に 満腔の謝意を捧げます．あわせて終始変わらぬ御教示と 御鞭撻を戴きました久留米大学医学部口腔外科学講座,

翁 玉香講師ならびに本講座, 若江秀敏講師に深謝いた します。

最後に，本研究に種々御協力を戴きました教室員各位 ならびに写真室, 角田文引氐, 電顕室, 佐藤敏正氏に感 解します。

\section{引用 文 献}

1) Frithiof, L. and Hagglund, G.: Ultrastracture of the capsular epithelium of radicular cysts. Acta odont. Scand. $24: 23-32,1966$.

2) Hansen, J. and Kobayashi, T. : Ultrastructural studies of odontogenic cyst. 1. Non-keratinizing cysts. Acta morph. Neerl-scand. 8:29-42, 1970.

3 ) Fejerskov, $\mathbf{O}$. and Krogh, J.: The calcifying ghost cell odontogenic tumor or the calcifying odontogenic cyst. J. oral Path. $1: 273-287,1972$.

4 ) Chen, S.Y. and Miller, A.S. : Ultrastructure of the keratinizing and calcifying odontogenic cyst. Oral Surg. 39:769-780, 1975.

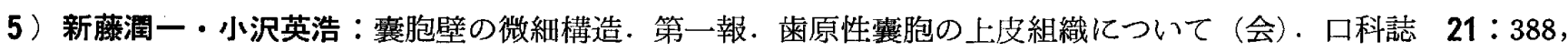
1972 .

6 ）新藤潤一一島崎能理子・志村介二：䨑根肉弐腫の電子顕微鏡的研究. 一特に上皮系の微細構造について一： 日口外誌 $25: 1290-1297,1979$.

7 ）岩佐俊明・㮩本昭二・伊藤透夫：濾胞性宷囊胞の電子顕微鏡的観察 (会).日口外誌 $21: 765 一 766,1974$.

8 ）岩佐俊明：歯原性顎囊胞の囊壁上皮の電子顕微鏡的研究. 特に角質囊胞について. 口病誌 $42: 381$-404, 1975.

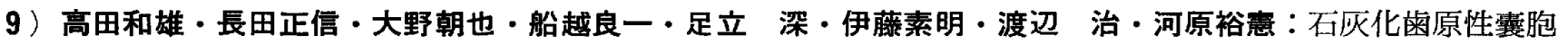
の 1 例. 日口外誌 $26: 654-664,1980$.

10）佐藤 徹・木村博人・武田俊平・木村典子・鈴木 貢：濾胞性歯囊胞の病態. 一とくに埋伏歯被膜と濾胞性 歯䧶胞の関係について一。日口外誌 $31: 2265-2268,1985$.

11）永田 睦：口腔領域各種疾患の走查型電子顕微鏡的研究. 一特に上皮細胞表面微細構造を中心として一。医 研究 $51: 1-32,1981$.

12）若江秀敏：菌原性囊胞の走查並びに透過電子頟微鏡的研究. 九州歯会誌 $36: 802-824,1982$.

13）広沢辰美・若江秀敏・熊埜御堂渉・橋本 滋 - 森 智昌・橋本建治・本田 聡・椎木康嗣・深江順吾 : 濾胞 性䨑囊胞の 2 例. 一原始性囊胞ならびに含菡性囊胞一。福雪大誌 $9: 276-286,1982$.

14）石川梧朗・秋吉正豊：口腔病理学 II . 永末畫店, 京都, $839-871,1979$.

15）福岛祥紘・石木哲夫：顎骨囊胞の新分類の提唱. 歯医学誌 $4: 50-63 ， 1985$.

16) Morgenroth, K. und Morgenroth, K. Jr. : Vergleichende stomatoskopische und rasterelektronenmikroskopische Untersuchungen von Mundschleimhautveränderungen. Dtsch. $z a-$ hnarztl. Z. $25: 199-207,1970$.

17) Whittaker, D.K. and Adams, D. : The surface layer of human foetal skin and oral mucosa: 
A study by scanning and transmission electron microscopy. J. Anat. $108: 453-464,1971$.

18）松本康博・丸谷雅晴・内田 隆・瀬戸皖一・渡辺義男：走查電子顕微鏡による口腔軟組織表面の微細構造の 観察. 1. 主として正常口腔粘膜について. 日口外誌 $21: 274-279,1975$.

19）斉藤 博・安藤規子・高木知道：重層扁平上皮の分化：走査電子顕微鏡による観察 (会). 解剖誌 $50 ： 52$ $-53,1975$.

20）高木知道・㖖藤 博・安蘇規子 : 微小堤の分化機構. ヒトの舌の上皮細胞表面形態の走查電子顕微鏡による 観察. 歯基礎誌 $18: 418-434,1976$.

21）高木知道：口腔粘膜の表面構造：ととに微小堤について．岩医大歯誌 $2 ： 125-135 ， 1977$.

22）丸谷雅晴・松本康博・瀬戸晥一・渡辺義男：走査電顕によるヒトの口腔粘膜上皮表層の微細構造の観察（会）， 日口外誌 $23: 941,1977$.

23）大神紀代子：正常および各種疾患における口腔粘膜の表面超微細構造の形態とその分布. 鶴晃匊学 8：137 $-166,1982$.

24) Olson, K.R. and Fromm, P.O. : A scanning electron microscopic study of secondary lamellae and chloride cells of rainbow tront (salmo gairdneri). Z. Zellforsch. mikrosk Anat. $143: 439-449,1973$.

25) Hughes, G.M. and Wright, D.E. : A comparative study of the ultrastructure of the waterblood pathway in the secondary lamellae of teleost and elasmobranch fishes-benthic forms. Z. Zellforsch. mikrosk Anat. $104: 478-493,1970$.

26) Sperry, D.G. and Wassersug, R.J. : A proposed function for microridges on epithelial cells. Anat. Rec. $185: 253-257,1976$.

27）杉原一正・塩田重利：口腔粘膜疾患の走査電子顕微鏡学的研究. 䍘塞礎誌 $19: 208-218,1977$.

28）山下佐英・杉原一正・永田 睦・川岛清美・浜崎栄作：口腔領域各種疾患の走查型電顕による観察. 菌界展 望 $55: 385-396,1980$.

29) Gorlin, R.J. : Potentialities of oral epithelium manifest by mandibular dentigerous cyst. O.S., O.M. and O.P. $10: 271-284,1957$.

30) Shear, M. : Secretory epithelium in the lining of dental cysts. J. Dent. Asso. of South Africa. $15: 117-122,1960$.

31) Browne, R.M. : Metaplasia and degeneration in odontogenic cysts in man. J. oral Path. $1: 145-158,1972$.

32）尾関雅彦：歯原性囊胞に出現する粘液細胞と線毛細胞に関する病理組織学的研究. 口病誌 50：193一211, 1983.

33）管 宇・榎本正二・高木 実：口腔病変の角化について. 口病誌 $49: 239-250,1982$.

34）小野富昭：病的角化に関する電子顕微鏡的観察. 口病誌 $37: 312-337,1970$. 